\title{
Numerical reconstructions of the Northern Hemisphere ice sheets through the last glacial-interglacial cycle
}

\author{
S. Charbit ${ }^{1}$, C. Ritz $^{2}$, G. Philippon ${ }^{1}$, V. Peyaud ${ }^{2}$, and M. Kageyama ${ }^{1}$ \\ ${ }^{1}$ LSCE/IPSL, CEA-CNRS-UVSQ, UMR 1572, CE Saclay, Orme des Merisiers, Bat. 701, 91191 Gif-sur-Yvette cedex, France \\ ${ }^{2}$ LGGE, CNRS, 54, rue Molière-BP96, 38402 Saint Martin d'Hères cedex, France
}

Received: 28 August 2006 - Published in Clim. Past Discuss.: 26 September 2006

Revised: 21 December 2006 - Accepted: 18 January 2007 - Published: 26 January 2007

\begin{abstract}
A 3-dimensional thermo-mechanical ice-sheet model is used to simulate the evolution of the Northern Hemisphere ice sheets through the last glacial-interglacial cycle. The ice-sheet model is forced by the results from six different atmospheric general circulation models (AGCMs). The climate evolution over the period under study is reconstructed using two climate equilibrium simulations performed for the Last Glacial Maximum (LGM) and for the present-day periods and an interpolation through time between these snapshots using a glacial index calibrated against the GRIP $\delta^{18} \mathrm{O}$ record. Since it is driven by the timing of the GRIP signal, the temporal evolution of the ice volume and the ice-covered area is approximately the same from one simulation to the other. However, both ice volume curves and spatial distributions of the ice sheets present some major differences from one AGCM forcing to the other. The origin of these differences, which are most visible in the maximum amplitude of the ice volume, is analyzed in terms of differences in climate forcing. This analysis allows for a partial evaluation of the ability of GCMs to simulate climates consistent with the reconstructions of past ice sheets. Although some models properly reproduce the advance or retreat of ice sheets in some specific areas, none of them is able to reproduce both North American or Eurasian ice complexes in full agreement with observed sea-level variations and geological data. These deviations can be attributed to shortcomings in the climate forcing and in the LGM ice-sheet reconstruction used as a boundary condition for GCM runs, but also to missing processes in the ice-sheet model itself.
\end{abstract}

\section{Introduction}

In addition to Greenland and Antarctica, massive ice complexes covering North America (Laurentide and Cordillera)

Correspondence to: S. Charbit

(sylvie.charbit@cea.fr) and the northern part of the Eurasian continent (Fennoscandia) developed during the last glacial cycle. The sea-level history inferred from coral dating (Bard et al., 1990; Bard et al., 1996a; Fairbanks, 1989) or the isotopic signals recorded in marine sediments (Bond et al., 1993; Waelbroeck et al., 2002) or ice cores (Andersen et al., 2004; Johnsen et al., 1995) have revealed that this period was characterized by several phases of growth and retreat of the ice sheets.

During the Last Glacial Maximum (LGM) and the subsequent deglacial period, the areal extent of the North American ice sheet is quite well constrained (Clark et al., 1993; Dyke and Prest, 1987). Moreover a reconstruction of the maximum limits of the Eurasian ice sheet for the Late Quaternary period, based on satellite observations of geomorphological features, aerial photographs and various types of geological data has recently been published (Svendsen et al., 2004) within the framework of the QUEEN project (Quaternary Environments of the Eurasian North project). However, as often outlined (Kleman et al., 2002; Marshall et al., 2002; Zweck and Huybrechts, 2005), large uncertainties remain about the shape, the volume and the thickness of these former ice sheets, and their evolution through time. The best way for these characteristics to be better constrained is the use of numerical modeling. In this view, several approaches have been followed during the past decade. The first one relies on glacio-hydro-isostasy models based on relative sealevel observations that account for the temporal evolution of the ice load and the subsequent rheological response of the geoid to surface loading. These models provide an estimate of either the global ice volume at the LGM (Milne et al., 2002; Yokoyama et al., 2000) or a reconstruction of the ice volume equivalent sea-level during the deglacial history (Lambeck et al., 2000; Lambeck et al., 2002) or prior to the LGM (Lambeck and Chappell, 2001). Similar models constrained both by sea-level data sets and by geological reconstructions of the ice margins are designed to give a 3D picture of individual ice sheet (Lambeck, 1995; Peltier, 1994, 2004). However, these latter approaches only provide

Published by Copernicus GmbH on behalf of the European Geosciences Union. 
ice-sheet reconstructions during the deglacial period, and not prior the LGM, with the exception of the recent work on the Fennoscandian ice sheet by Lambeck et al. (2006). Moreover, these models present several intrinsic shortcomings. Firstly, they are hand-tuned to fit with relative sea-level data with no meaningful extractable error bar, and in regions in which data is unavailable the ice thickness is often underconstrained. Secondly, they cannot provide a unique solution to reconstruct the temporal history of the ice thickness, and finally they have neither intrinsic glaciological nor climatic self-consistency.

A second approach consists in using ice-sheet models. Two approaches have generally been followed. The first one relies on simplified climate models (energy balance models or Earth climate model of intermediate complexity) coupled to 2-D vertically integrated ice-sheet models (e.g., (Deblonde and Peltier, 1991; Deblonde et al., 1992; Gallée et al., 1992; Marsiat, 1994; Peltier and Marshall, 1995; Tarasov and Peltier, 1997). The second approach is based on the use of 3D dynamical ice-sheet models asynchronously coupled to an EBM (Tarasov and Peltier, 1999) or used in a forced mode. In this latter case, the climate forcing can simply be derived from ice core data (Greve et al., 1998; Huybrechts, 2002; Ritz et al., 1997) or from GCM climate snapshots interpolated through time using a glacial index generally inferred from the GRIP $\delta^{18} \mathrm{O}$ signal (Charbit et al., 2002; Marshall et al., 2002; Marshall et al., 2000; Tarasov and Peltier, 2004; Zweck and Huybrechts, 2005) which accounts for the rapid climate variability which occurred during the last glacial period. However, the climate recorded at the GRIP site results from the external forcings (i.e. insolation, greenhouse gases, aerosols) added to all internal climate feedbacks that may have occurred, but at the GRIP location only. Therefore, if some feedbacks are only activated at the GRIP site they can produce artifacts in other regions, and conversely, if feedbacks are not seen in the GRIP site but are important in other regions, they will be missing in the climate forcing.

Studies based on simplified climate and/or ice-sheet models generally aim at examining which kind of processes enable a reasonable simulation of the ice volume through the last glacial-interglacial cycle. Although the global ice volume at the LGM is generally quite well reproduced, the reconstruction of the spatial distribution of the individual ice masses and their specific shape often suffers from major drawbacks such as an insufficient southward extent of the North American ice sheet (Deblonde and Peltier, 1991; Gallée et al., 1992; Marsiat, 1994), an erroneous simulation of the Eurasian sector (Deblonde and Peltier, 1991; Deblonde et al., 1992; Tarasov and Peltier, 1997), a too much extended ice-covered area over Alaska, and the growth of ice in the Siberian region (Deblonde et al., 1992; Marsiat, 1994; Peltier and Marshall, 1995). These models often fail in successfully simulating the deglaciation process without incorporating any ad hoc process (Deblonde and Peltier, 1991; Gallée et al., 1992; Peltier and Marshall, 1995).
The evolution of ice sheets during the last glacial cycle is expected to be in better agreement with geological data when using 3-D thermo-mechanical ice-sheet models. However, large differences are observed between the results provided, for example, by the studies of Tarasov and Peltier (1999), Marshall et al. (2000), Bintanja et al. (2002) or Zweck and Huybrechts (2005). These differences appear in the magnitude and in the timing of the maximum ice volume, in the ice thickness and more generally in the shape of the ice sheets, in the repartition of ice between Eurasia and North America, in the erroneous simulation of ice over Alaska and Siberia, and finally in the timing of the deglaciation process.

A third alternative approach proposed by Tarasov and Peltier (2004) consists in taking advantage of both methods. Using a 3-D thermo-mechanical ice-sheet model, they performed a set of simulations where the model parameters were varied in order to explore the large phase space of possible solutions produced by glaciological models, and their reconstruction was constrained by a high resolution digitized ice margin chronology, geodetic observations of the present-day uplift at Yellowknife and gravity measurements. However, this work has only been performed for the North American ice sheet.

The different sources of uncertainties in the approach followed with 3-D ice-sheet modeling may come from the climate reconstruction used to force the ice-sheet model, that is from the climate model or from the basis of the climatic index method and finally from the choice of the index itself. It has been demonstrated that the use of climatic outputs coming from 17 GCMs leads to considerable scatter in the computed mass balance of the ice sheets (Pollard and Groups, 2000). Moreover the GCM climate also depends on the icesheet boundary condition for GCM simulations. In turn, the second cause which may be at the origin of the discrepancies between the results provided by different groups lies in the choice of the ice-sheet model, or more specifically in the choice of some physical parameters related to ice flow, that are under-constrained (Marshall et al., 2002).

In this paper we focus on the uncertainties linked to the climate forcing. To this end we used climatic outputs from different atmospheric general circulation models (AGCMs) involved in the first Paleoclimate Modelling Intercomparison Project (PMIP, Joussaume and Taylor, 1995) to force a single 3-D ice-sheet model of the Northern Hemisphere. Among the 22 PMIP models, only 10 of them provided snapshot climate simulations of the LGM and the present-day periods with fixed sea surface temperatures (SSTs) and sea ice cover. We removed from our selection the older version of the GCM developed at the Laboratoire de Météorologie Dynamique (i.e. LMD4), as well as the model which has the lowest resolution. For the present study, we chose six of the eight remaining models to keep a representative range of spatial horizontal resolutions of the PMIP-GCMs.

The aim of the present study is twofold. First it is to document the differences between the simulated spatial distribu- 
tions of the ice sheets and the evolution of the ice volumes. Secondly, it is to investigate to which extent it is possible to evaluate the ability of PMIP-GCMs to produce ice sheets in agreement with geological data and observed inferred eustatic sea level variations, and whether the LGM ice sheets are consistent with the reconstruction used as a boundary condition for the LGM GCM runs.

\section{Description of the approach}

\subsection{The ice-sheet model}

A full description of GREMLINS (GREnoble Model of Land Ice of the Northern HemiSphere) can be found in (Ritz et al., 1997). In the present paper we just recall the main characteristics of the model. It is a three dimensional thermomechanical ice-sheet model which predicts the evolution of the geometry (extension and thickness) of the ice and the coupled temperature and velocity fields. This model only accounts for grounded ice without incorporating a description of ice flow through ice streams and does not deal with ice shelves. The equations are solved on a Cartesian grid $(45 \mathrm{~km} \times 45 \mathrm{~km})$ corresponding to $241 \times 231$ grid points of the Northern Hemisphere. The evolution of the ice sheet surface and geometry is a function of surface mass balance, velocity fields, and bedrock position. The isostatic adjustment of bedrock in response to the ice load is governed by the flow of the asthenosphere with a characteristic time constant of 3000 years, and by the rigidity of the lithosphere. The temperature field is computed both in the ice and in the bedrock by solving a time-dependent heat equation. Changes in the ice thickness with time are computed from a continuity equation and are a function of the ice flow, the surface mass balance and the basal melting. The ice flow results both from internal ice deformation and basal sliding. It is calculated with the zeroorder shallow ice approximation.

The surface mass balance is the sum of accumulation and ablation, both of which depending on surface air temperature (colder air leads to increased aridity). The accumulation term is inferred from the AGCM mean annual air temperature and total precipitation fields. The fraction of solid precipitation is considered to be proportional to the fraction of the year with mean daily temperature less than $2^{\circ} \mathrm{C}$. The mean daily temperature is computed from mean annual and summer (June-August) air temperatures provided by the GCM. We use the mean annual and summer AGCM fields, and the seasonal cycle is reconstructed assuming a sine wave with the amplitude given by the difference between summer and annual temperatures. The ablation term is computed using the positive-degree-day (PDD) method, which is based on an empirical relation between air temperatures and melt processes. In the present study, this method is used exactly as the same way as described in (Reeh, 1991) and accounts for albedo differences between snow and ice and for the production of superimposed ice due to meltwater that refreezes.

Although the ice calving is not explicitly computed in the model, it is parameterized in the following way: the ice lost by calving is set to 0 when ice begins to float. This cut-off condition is not imposed at each time step so that ice is allowed to advance over the continental shelf. Consequently, if the sea-level drops, but there is still water in a given location, the ice sheet can expands over the sea.

\subsection{The forcing method}

The forcing method is explicitly described in (Charbit et al., 2002). In this section we summarize its basic principles. Due to their high computational cost, the general circulation models can only provide snapshots of climate. Hence, we used two climate snapshots, one for a glacial period, the Last Glacial Maximum (21 kyr BP), and one for the present-day period, representing two extreme climates of the last glacialinterglacial cycle. To obtain a time-dependent climatology over the entire cycle, the AGCM fields used to drive the icesheet model are interpolated through time (see below). These fields are the 2-m mean annual and summer surface air temperatures and the annual precipitation and they are used to compute both ablation and accumulation. To minimize the errors due to GCM deficiencies, we use a pertubative method of the present-day climate: the anomaly fields are computed as a difference for temperature and as a ratio for precipitation between simulated control (ctrl) and past (paleo) climates (Fig. 1). As these variables are strongly influenced by local topography, corrections of precipitation are required to account for surface elevation difference between the GCM and the ice-sheet model. For temperature, we apply a vertical gradient derived from empirical observations in Greenland (Ohmura and Reeh, 1991): $8^{\circ} \mathrm{C} / \mathrm{km}$ and $6.5^{\circ} \mathrm{C} / \mathrm{km}$ for annual and summer temperature. These lapse rates rather resemble moist adiabatic free-atmosphre lapse rates rather than near-surface values $\left(\sim 4^{\circ} \mathrm{C} / \mathrm{km}\right)$ reported by Marshall et al. (2006) for the Ellesmere Island region. The sensitivity of our results to less steep lapse rates will be investigated in the future. To account for less moisture at high altitude we assume that precipitation is exponentially dependent on temperature. Therefore a difference of temperature corresponds to a ratio of precipitation. The corrected AGCM anomalies $\Delta T_{\mathrm{cor}, \mathrm{GCM}}(t)$ and $\Delta P_{\mathrm{cor}, \mathrm{GCM}}(t)$ can be written as:

$$
\begin{aligned}
& \Delta T_{\mathrm{cor}, \mathrm{GCM}}(t)=\left(T_{\mathrm{paleo}, \mathrm{GCM}}-T_{\mathrm{ctrl}, \mathrm{GCM}}\right)(t) \\
& \quad+\lambda \cdot\left(S_{\text {paleo, } \mathrm{GCM}}-S_{\mathrm{ctrl}, \mathrm{GCM}}\right) \\
& \Delta P_{\mathrm{cor}, \mathrm{GCM}}(t)=\exp \left(0.05 \times\left(T_{\text {paleo, GCM }}-T_{\mathrm{ctrl}, \mathrm{GCM}}\right)\right) \\
& \quad \times \frac{P_{\text {paleo }, \mathrm{GCM}}}{P_{\text {paleo, GCM }}}(t)
\end{aligned}
$$




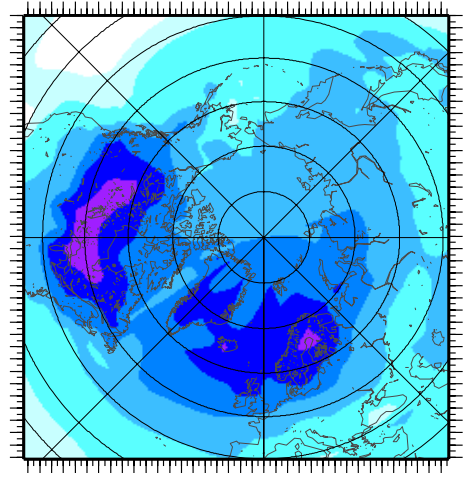

LMD5

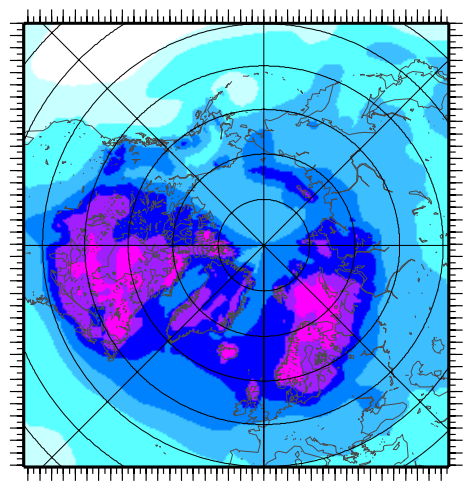

GENESIS2

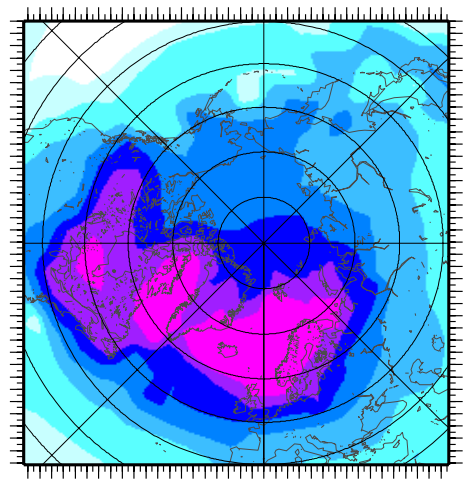

CCSR 1

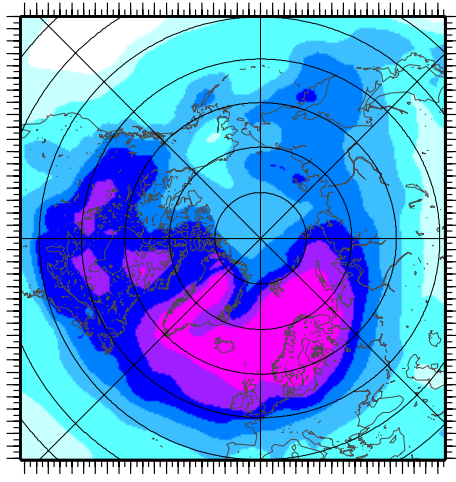

ECHAM3

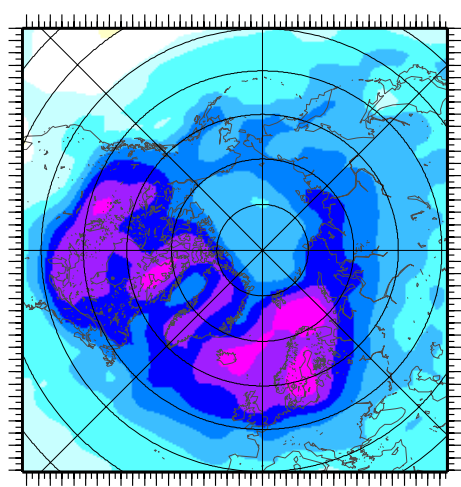

UGAMP

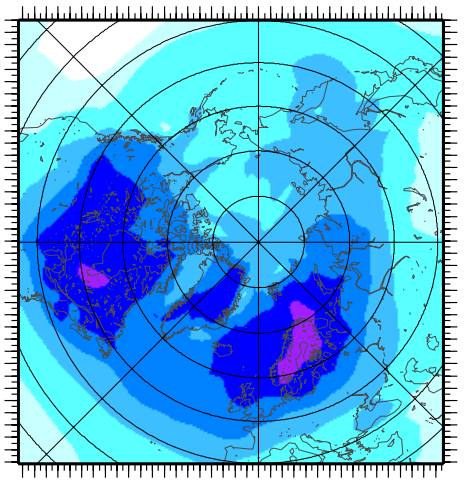

MRI2

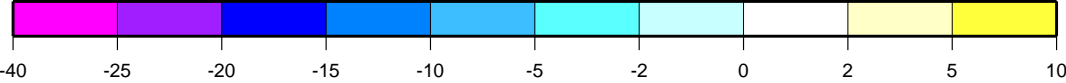

Fig. 1a. Mean annual surface air temperature differences between past $(21 \mathrm{kyr})$ and present simulated by each of the atmospheric general circulation model and interpolated on the ice-sheet model grid.

where $T, P, S$ and $\lambda$ are related to temperature, precipitation, surface elevation and vertical lapse rate. The exponential term in the anomaly of precipitation accounts for all processes that are linked to a difference of temperature be- tween past and present. The numerical value 0.05 is deduced from the temperature-precipitation relationship in the same way as in (Charbit et al., 2002). These anomalies are then interpolated on the ice-sheet model (ISM) grid (see below 


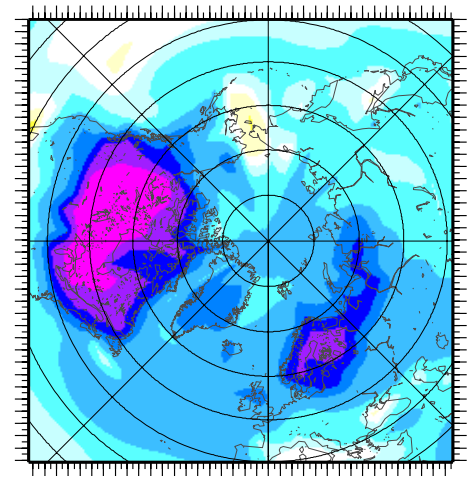

LMD5

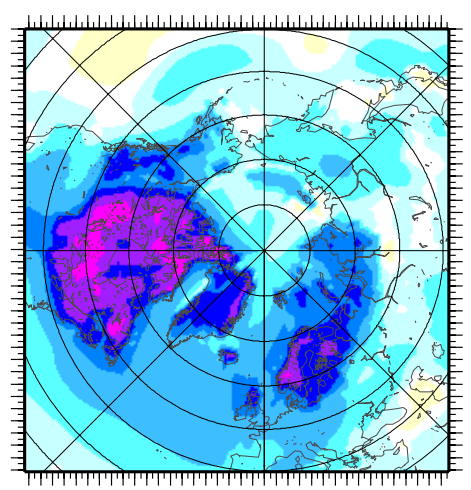

GENESIS2

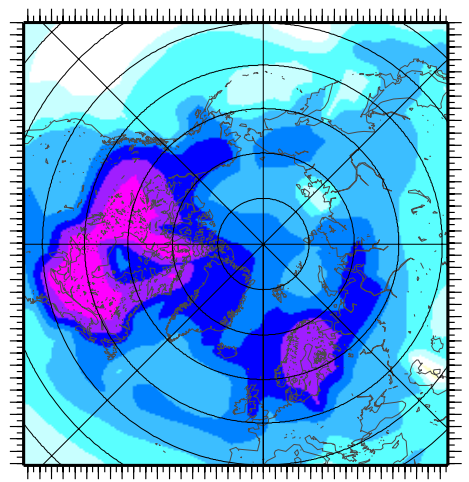

CCSR 1

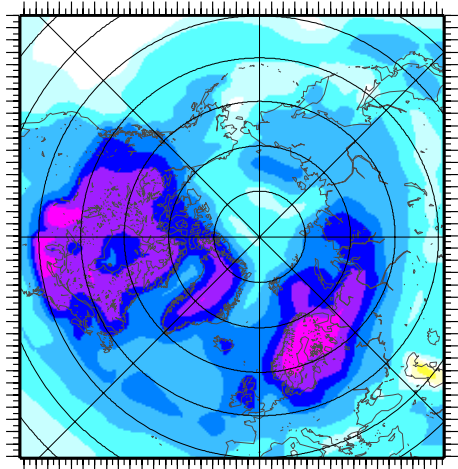

ECHAM3

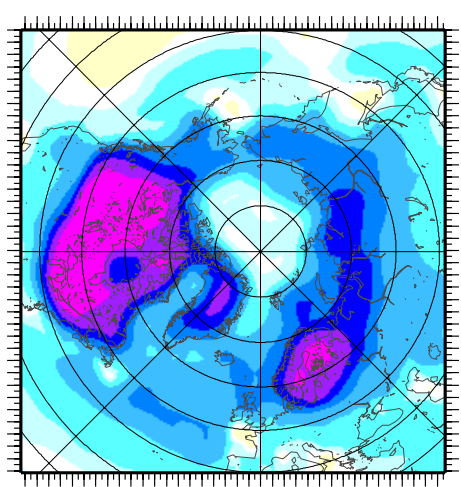

UGAMP

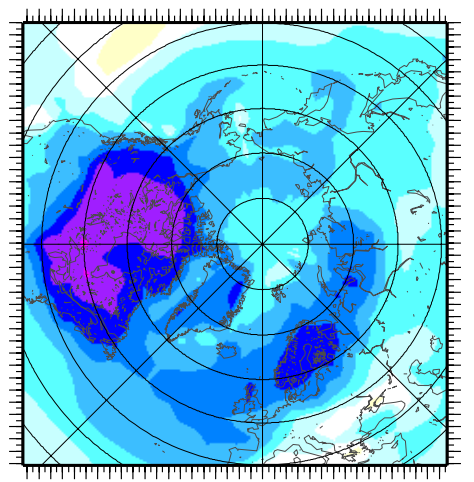

MRI2

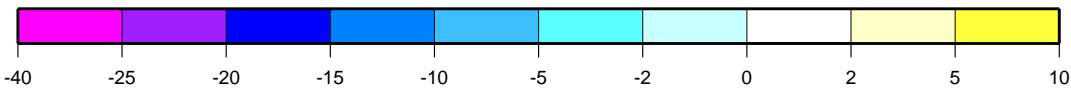

Fig. 1b. Same as Fig. 1a for the mean summer surface air temperature.

$\Delta T_{\text {cor,ISM }}(t)$ and $\left.\Delta P_{\text {cor,ISM }}(t)\right)$. The time-dependent climatology is obtained by interpolating through time these latter anomalies using a climatic index inferred from the $\delta^{18} \mathrm{O}$ GRIP record, so that at each time step, the climatic fields used to force GREMLINS can be expressed with:

$\Delta X_{\mathrm{ISM}}(t)=(1-\alpha(t)) \Delta X_{\mathrm{LGM}}$

where the $\alpha$ coefficient represents the proportion of interglacial climate ( $\alpha=0$ for the LGM and $\alpha=1$ for the presentday period), and $\Delta X_{\mathrm{LGM}}$ stands for the corrected anomaly of 


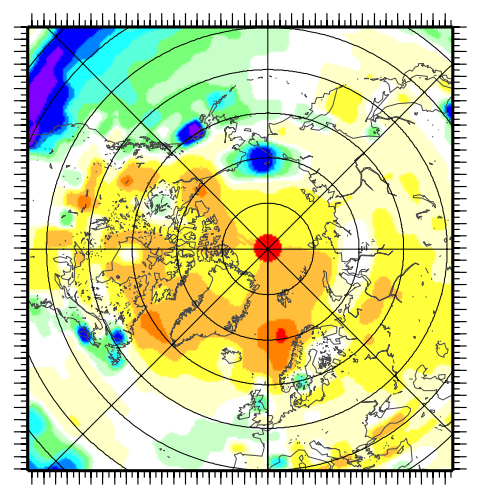

LMD5

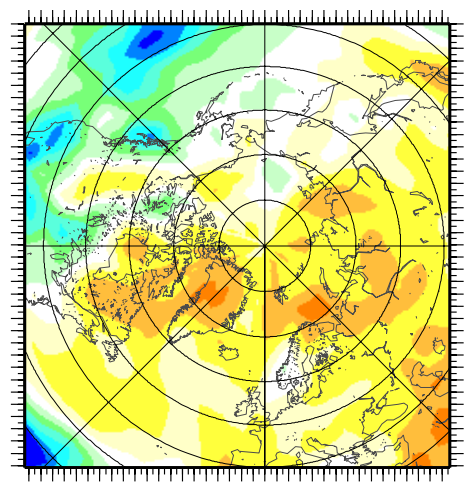

GENESIS2

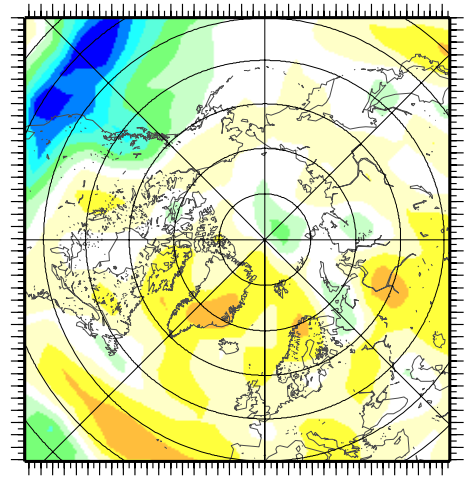

CCSR 1

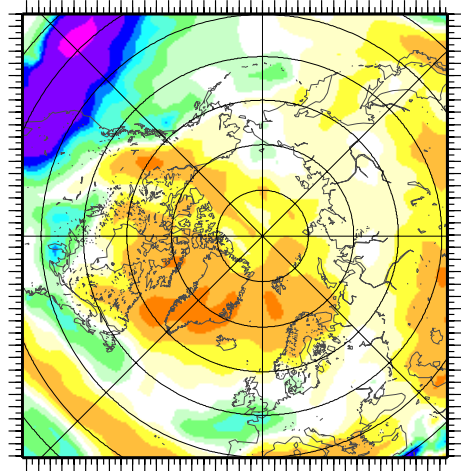

ECHAM3

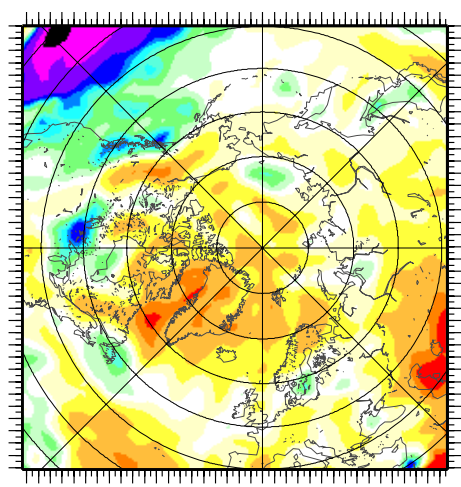

UGAMP

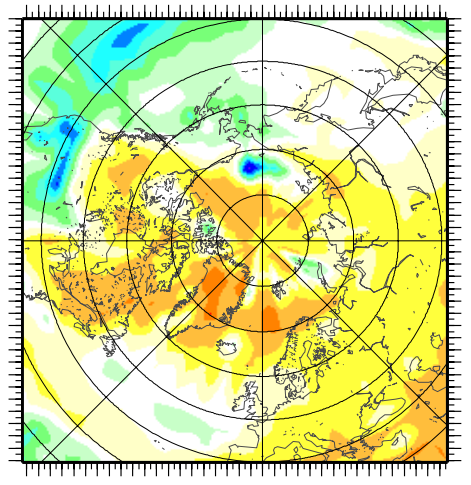

$\mathrm{MRI} 2$

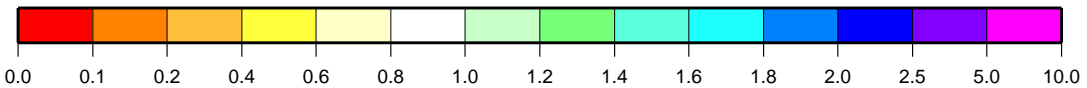

Fig. 1c. Mean annual precipitation ratio between past $(21 \mathrm{kyr})$ and present simulated by each of the atmospheric general circulation model and interpolated on the ice-sheet model grid.

temperature or precipitation. This approach is similar to the one previously used in (Marshall et al., 2000) or (Charbit et al., 2002). The main assumption is that the spatial patterns of temperature or precipitation variations (i.e. between past and present) do not change with time, and that the climatic variations are only driven by the temporal variations of the $\alpha$ coefficient. The temperature at the surface of the ice-sheet model $\left(T_{\text {rec }}\right)$ is reconstructed at each time step from the re- 
Table 1. Model resolution and boundary conditions of the AGCMs runs.

\begin{tabular}{lccccccc}
\hline Models & $\begin{array}{c}\text { Resolution } \\
\text { (long } \times \text { lat } \times \text { vert. })\end{array}$ & $\begin{array}{c}\text { SST } \\
(21 \mathrm{ka})\end{array}$ & $\begin{array}{c}\text { SST } \\
(0 \mathrm{ka})\end{array}$ & $\begin{array}{c}\text { Sea ice } \\
(21 \mathrm{ka})\end{array}$ & $\begin{array}{c}\text { Sea ice } \\
(0 \mathrm{ka})\end{array}$ & $\begin{array}{c}\text { Orography } \\
(21 \mathrm{ka})\end{array}$ & $\begin{array}{c}\text { Orography } \\
(0 \mathrm{ka})\end{array}$ \\
\hline ECHAM3 & $128 \times 64 \times 19$ & PMIP & AMIP & CLIMAP 21 ka & AMIP & PMIP & AMIP \\
UGAMP & $128 \times 64 \times 19$ & CLIMAP 21 ka & AIMob_76 & CLIMAP 21 ka & AIMob_76 & PMIP & AMIP \\
CCSR1 & $64 \times 32 \times 20$ & PMIP & AMIP & CLIMAP 21 ka & AMIP & PMIP & ETOPO5_85 \\
GENESIS2 & $96 \times 48 \times 18$ & CLIMAP 21ka & Shea_90 & CLIMAP 21 ka & Shea_90 & PMIP & US Navy-FNOC_85 \\
LMD5 & $64 \times 50 \times 11$ & PMIP & AMIP & CLIMAP 21 ka & AMIP & PMIP & AMIP \\
MRI2 & $72 \times 46 \times 15$ & PMIP & AMIP & CLIMAP 21 ka & AMIP & PMIP & AMIP \\
\hline
\end{tabular}

Column 2 : Horizontal resolution and number of vertical levels for each model (column 2);

Columns 3-8 indicate how the boundary conditions (SSTs, sea-ice cover and orography) have been taken into account for each GCM run:

Column 3: $[$ PMIP] = CLIMAP $21 \mathrm{kyr} \mathrm{BP}-$ CLIMAP $0 \mathrm{ka}+$ SSTs data used for the control run (see column 4)

Column 4: [AMIP] = Reynold's data (1979-1988)-10 years mean (Reynolds, 1988); AIMob_76 = data from Alexander and Mobley (1976);

Shea_90 = data from Shea et al. (1990)

Column 5: data from (CLIMAP, 1981)

Column 6: $[\mathrm{AMIP}]=$ data from US Navy and National oceanic an Atmospheric Administration, AIMob_76 = data from Alexander and Mobley (1976)

Column 7: $[\mathrm{PMIP}]=\mathrm{ICE}-4 \mathrm{G}(21 \mathrm{ka})-\mathrm{ICE}-4 \mathrm{G}(0 \mathrm{ka})+$ orography used for the control run (see column 8$)$

Column 8: [AMIP] = US Navy $10^{\prime} \times 10^{\prime}$ dataset (Joseph, 1980); US navy-FNOC_85: area-averaged dataset over each atmospheric grid box (Kineman, 1985); ETOPO5_85 = obtained at a resolution of $5^{\prime} \times 5^{\prime}($ Edwards, 1989)

sulting anomaly $\Delta T_{\mathrm{ISM}}(t)$ added to the present-day climatology $\left(T_{\text {clim }}\right)$ and a corrective factor accounting for the surface elevation difference between past and present:

$T_{\text {rec }}=T_{\text {clim }}-\lambda\left(S_{\text {paleo,ISM }}-S_{\text {ctrl,ISM }}\right)+\Delta T_{\text {cor,ISM }}(t)$

In the same way, the reconstructed precipitation is derived from the product of $\Delta P_{\mathrm{ISM}}(\mathrm{t})$ and the observed precipitation. The impact of the temperature difference between past and present is accounted for by the exponential term:

$P_{\text {rec }}=P_{\text {clim }} \times \exp \left(0.05 \times\left(T_{\text {rec }}-T_{\text {clim }}\right)\right) \times \Delta P_{\text {cor }, \text { ISM }}(t)$

The present-day topography is based on the GLOB-ETOPO2 dataset and the Greenland bedrock has been elaborated by Bamber et al. (2001).

The present-day climatology is based on the ERA-40 reanalyses for the temperature fields. The precipitation is derived from a compilation between the CRU dataset over continents (New et al., 1999) and the GPCP dataset over oceans (Adler et al., 2003). Moreover, for the Arctic area, the precipitation data is provided by Serreze and Hurst (2001).

It is worth noting that owing to the fact GREMLINS is not fully coupled to the GCMs, the present approach cannot account for the changes in atmospheric circulation and in the albedo effect due to changes in the ice sheets geometry. Other artifacts are also introduced by using LGM climate snapshots which strongly influences our representation of past climate throughout the last glacial-interglacial cycle by overestimating the albedo effect in regions which were covered by snow at the LGM. In the following, we call this effect the "artifact albedo effect".

\subsection{The experimental set-up}

The specificities of the AGCM runs used in this study are summarized in Table 1. All the six models used in this study have been forced by i) the insolation at the top of the atmosphere (Berger, 1978), ii) the atmospheric $\mathrm{CO}_{2}$ inferred from ice core measurements (Raynaud et al., 1993), iii) the prescribed seasonally varying sea surface temperatures and the sea-ice cover, both derived from the CLIMAP dataset (CLIMAP, 1981) for the LGM climate and from observations for the control run (i.e. present-day run), iv) the LGM sea-level lowering and the ice-sheet geometry (extent and altitude) obtained from the LGM ICE-4G reconstruction (Peltier, 1994) and from the observations for the presentday climate (http://www-lsce.cea.fr/pmip/). For the UGAMP and the GENESIS2 models the SSTs from the CLIMAP reconstruction have been directly used as boundary conditions for the LGM run, while for the other models (ECHAM3, LMD5, MRI2 and CCSR1) the prescribed SSTs are reconstructed from the CLIMAP (1981) changes between past and present added to the present-day observations used for the control run. In the same way, for all models, the ice-sheet topography is given by the topography anomaly between past and present obtained from the differences between the LGM and the present-day ICE-4G reconstructions (Peltier, 1994), added to the present-day topography coming from the observations (see Table 1).

Although the analyses presented in this paper focus on the last glacial cycle (130-0 kyr BP), the ice-sheet model is run for $230 \mathrm{kyr}$ for model spin-up. This procedure is necessary to obtain a reasonable vertical profile of temperature in the ice, 


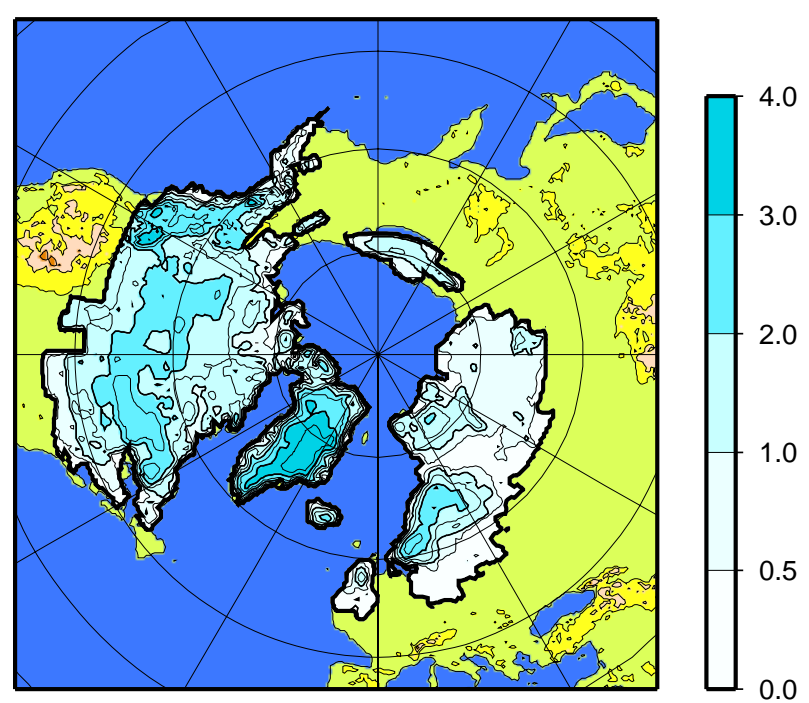

Fig. 2. Extension and ice thickness (in $\mathrm{km}$ ) of the Northern Hemisphere ice sheets predicted by the ICE-4G model (Peltier, 1994).

and to a lesser extent, to integrate the history of the bedrock response to changes in surface loading. The initial topography is given by the present-day topography and the climate forcing is obtained from the method previously described.

\section{Results}

\subsection{Spatial distribution}

Time slices of the simulated spatial distributions of the ice sheets are represented in Figs. 3-7 at different key periods of the last glacial cycle. These maps exhibit large differences both in altitude and ice-covered areas from one simulation to the other. Although our discussion mainly focuses on the simulated North American and Eurasian ice sheets, it is worth noting that differences are also observed in the extent and the altitude of the Greenland ice sheet throughout the simulation. However, at the present-day period (Fig. 7), the six experiments are in full agreement concerning the extent of Greenland and its ice thickness and match with observations. Moreover, the simulated American and Eurasian ice sheets have almost completely melted, although small ice masses are still present over the Baffin Island and the Arctic Ocean.

\subsubsection{The North American ice sheet}

The most important point at the early phase of glaciation (113 kyr BP, Fig. 3) is related to the location of the inception sites. All models produce ice over the Canadian Archipelago, the Baffin Island and over the Northern Rocky Mountains. In the simulations performed with GENESIS2, UGAMP and
CCSR1 ice also covers the Keewatin region, while small ice caps are produced in the Labrador sector with LMD5 and CCSR1, and in the Hudson Bay lowland with CCSR1 and UGAMP. Observational data (Andrews and Barry, 1978) indicate that the regions of ice-sheet inception in North America were those bordering the Eastern coast, such as the Baffin Island and the Quebec-Labrador region, as well as the uplands of Northeastern Keewatin. This is concordant with our reconstructions, except for the Labrador sector where small ice caps are only produced with two models. Moreover, the advance of ice in the Middle West region is highly discordant with the geological data. The excess of ice in this area, simulated by using UGAMP outputs as climate forcing, seems to be directly related to a high precipitation ratio added to a small anomaly of temperature. Paleoenvironmental records indicate that, at the early beginning of the glaciation, climate in the Rocky Mountains regions was as warm as, or warmer than present (Clark et al., 1993). Hence, the Cordilleran ice sheet does not appear to have developed before the late isotopic stage 5 or 4 (i.e. $\sim 75 \mathrm{kyr} \mathrm{BP}$ ). At that time, the ice advanced over the Southern British Columbia and into the Northern Puget lowland, whereas northern areas were later covered by ice, which is in contradiction with our modeling results. This discordance can be explained by the shortcomings of our approach. Actually, according to a study carried out by Clark and Bartlein (1995), the Cordilleran ice sheet started to grow when the Laurentide ice sheet was high enough to induce a displacement of the jet stream causing precipitation to fall over the Rocky Mountains (Roe and Lindzen, 2001). Such a glaciation sequence cannot be represented with our methodology because it does not account for the feedbacks of the ice sheets on the atmospheric circulation. Moreover, the use of LGM climate snapshots in the climate forcing induces an artifact albedo effect (see Sect. 2.2) in regions covered by snow at the LGM, and hence favours the glaciation process at any time of the last glacial-interglacial cycle.

The results obtained for the $112 \mathrm{kyr}$ BP period (Fig. 4) confirm that for the CCSR1 model the regions of early glaciation (Labrador-Quebec, Rockies and Keewatin) coalesce to form the North American ice sheet. A dome develops over South Keewatin in the simulation performed with the UGAMP model and ice has coalesced with that covering the Northern part of the ice sheet and that spreading over the Cordilleran region. The western sector of the Laurentide ice sheet, as well as the Labrador and the Rocky Mountains regions, have widely extended compared to the $113 \mathrm{kyr} \mathrm{BP}$ period (Fig. 3). The rapid expansion of the ice is probably due to the artifact albedo effect due to the use of LGM climate snapshots, as previously mentioned. The simulations performed with ECHAM3 and GENESIS2 are characterized by an expansion of ice in the Middle West region, whereas for the MRI2 model, the only ice-covered area is the Northern part of Canada. 


\section{LMD5}

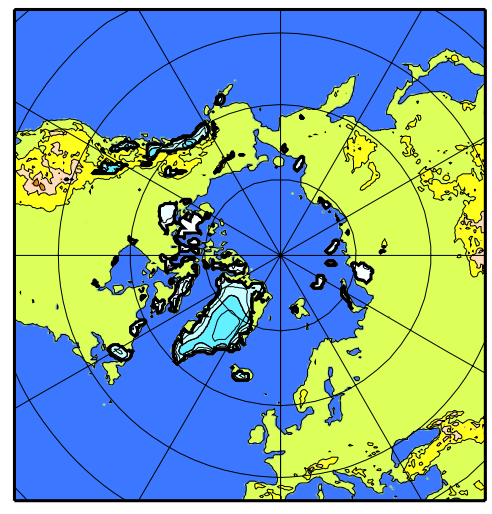

\section{GEN2}

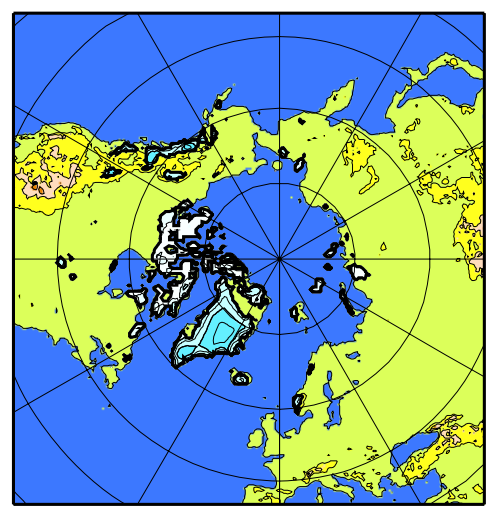

\section{CCSR 1}

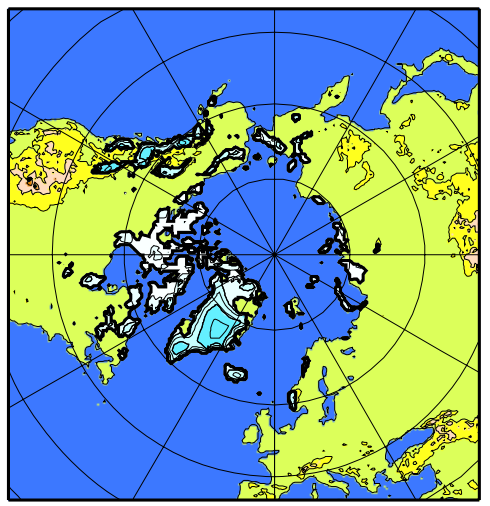

\section{ECHAM3}

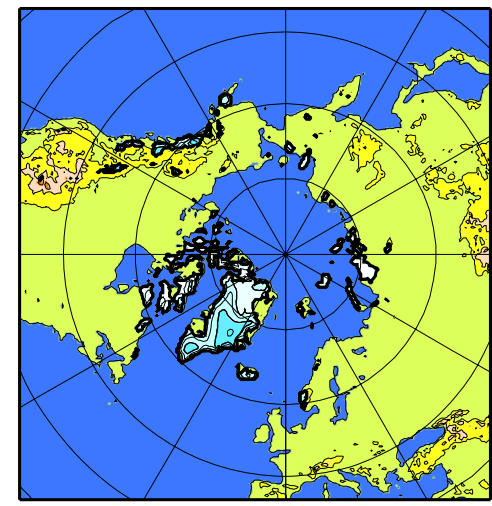

\section{UGAMP}

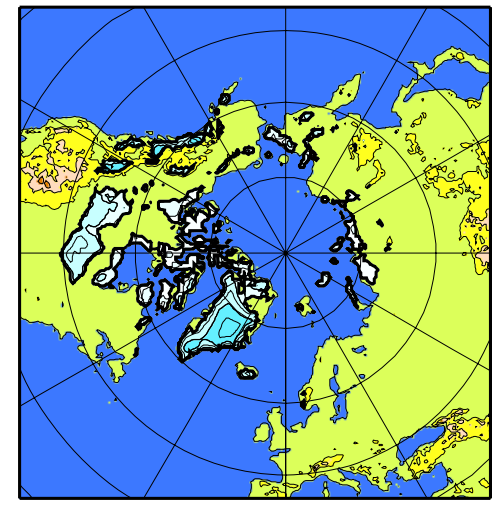

MRI2

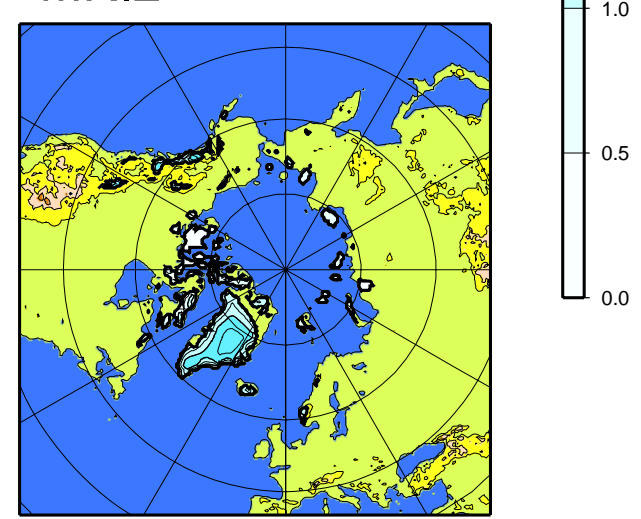

\section{3 kyr BP}

Fig. 3. Spatial distribution of the simulated ice sheets at $113 \mathrm{kyr} \mathrm{BP}$ which corresponds to the early phase of the glacial inception.

According to the ice volume curves (Fig. 8) the full glacial period starts after the last major phase of glaciation at around $57 \mathrm{kyr} \mathrm{BP}$ (Fig. 5). These maps indicate that the largest differences from one model to the other concern the shape of the North American ice sheet, the extent of Fennoscandia (see following section) and the presence of ice in Alaska and Siberia. According to geological records, the inception of ice in Keewatin and in the Quebec-Labrador Plateau leads 


\section{LMD5}

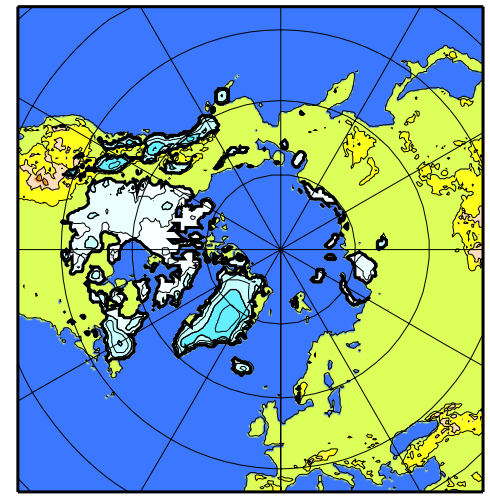

\section{GEN2}

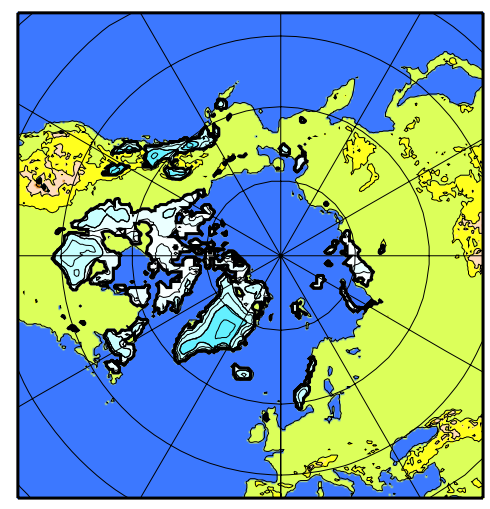

CCSR1

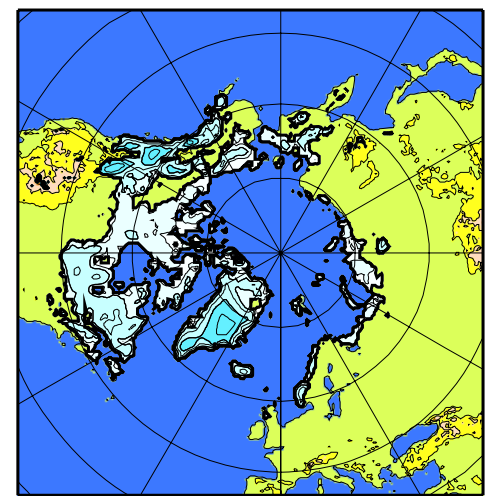

ECHAM3

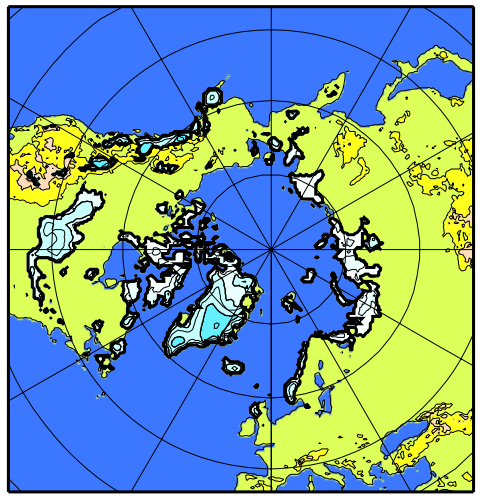

UGAMP

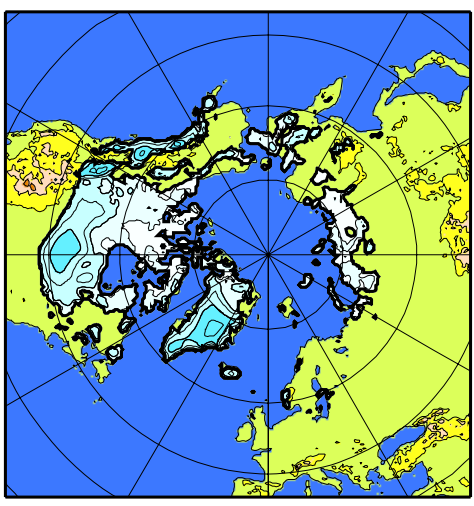

$\mathrm{MRI} 2$

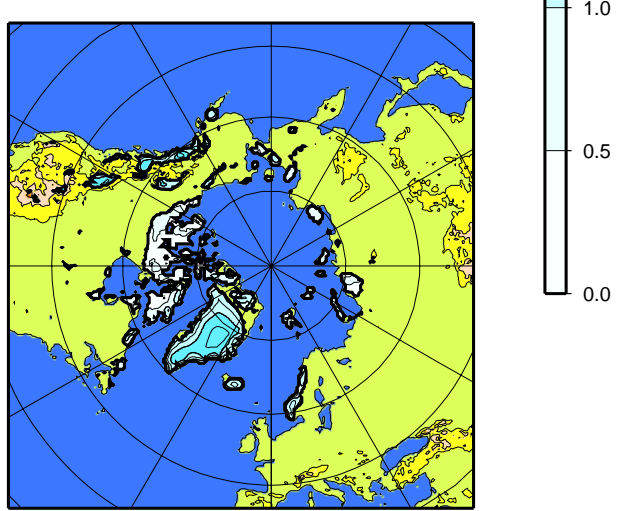

\section{2 kyr BP}

Fig. 4. Same as Fig. 4 for the 112 kyr BP period.

to the coalescence of both ice masses and to the formation of two domes centred on these sectors. However, none of the simulations presented in this study is able to reproduce a bi-domed ice-sheet. This is partly due to the fact that this structure does not appear in the LGM ICE-4G reconstruction
(Fig. 2) used as a boundary condition for the GCM simulation, but can also be linked to the ice-sheet model itself which does not account for sediment deformation. Actually, past studies have found that strong geographically constrained fast flow due to till-deformation when sediment is water- 


\section{LMD5}

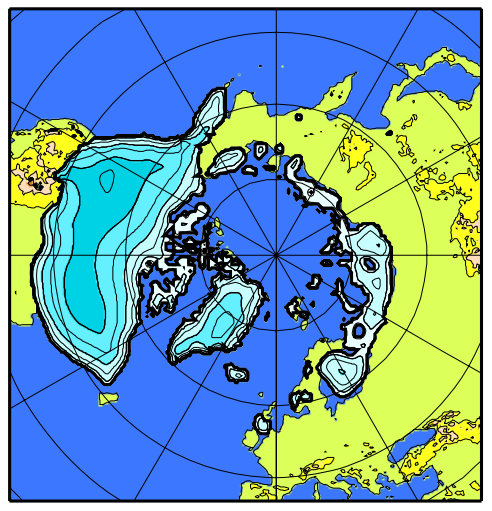

GEN2

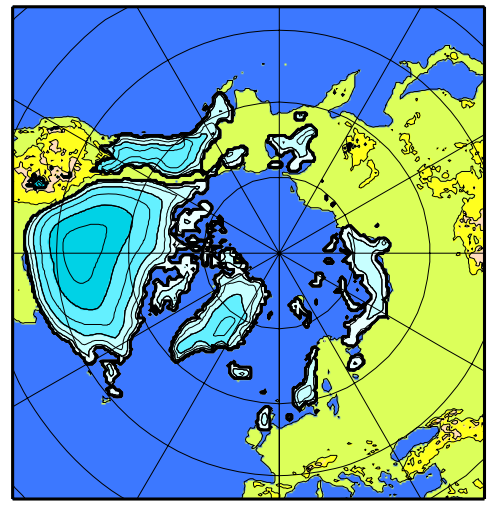

CCSR1

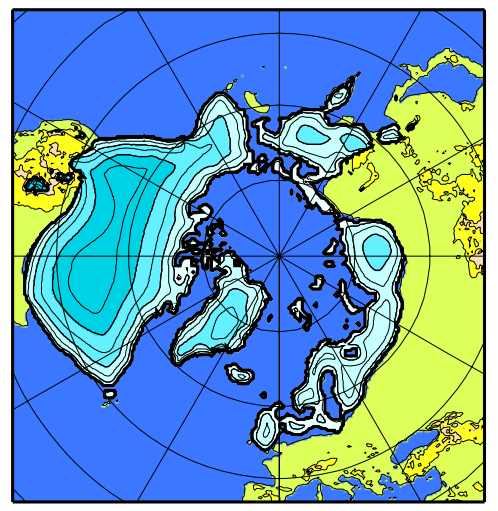

ECHAM3

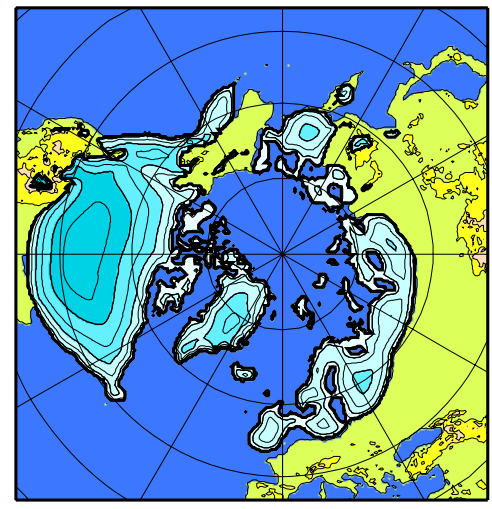

UGAMP

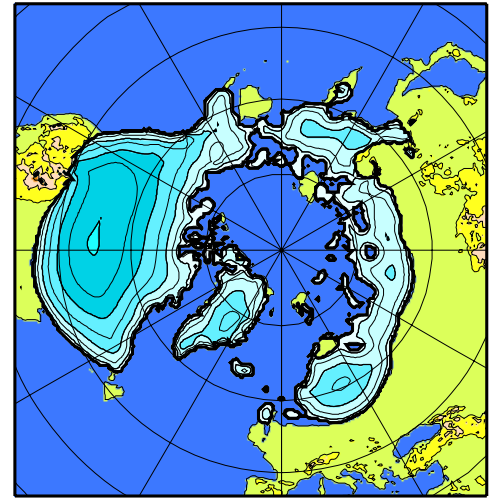

MRI2

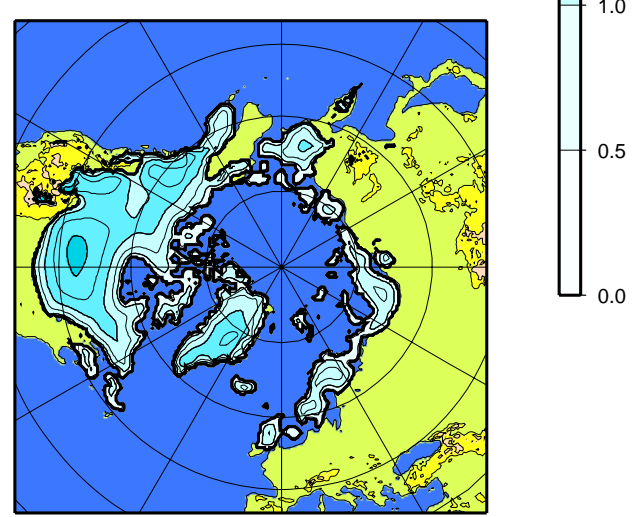

57 kyr BP

Fig. 5. Same as Fig. 4 for the $57 \mathrm{kyr}$ BP period which corresponds to a full glacial state.

saturated was required to obtain a multi-domed ice surface topography that fits relative sea-level constraints (Tarasov and Peltier, 2004). The second deviation from geological records concerns the Cordilleran ice sheet; as outlined in the synthesis provided by Clark et al. (1993), the ice sheet was only a little more extensive than today during its first phase of development, and completely disappeared before the end of stage $4(\sim 59 \mathrm{kyr} B P)$. It then started to readvance by 25 - 
LMD5

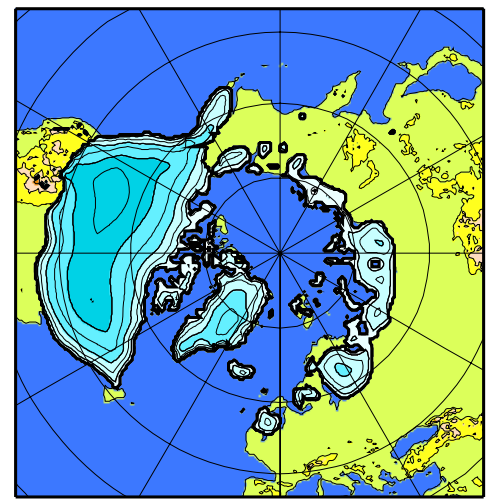

GEN2

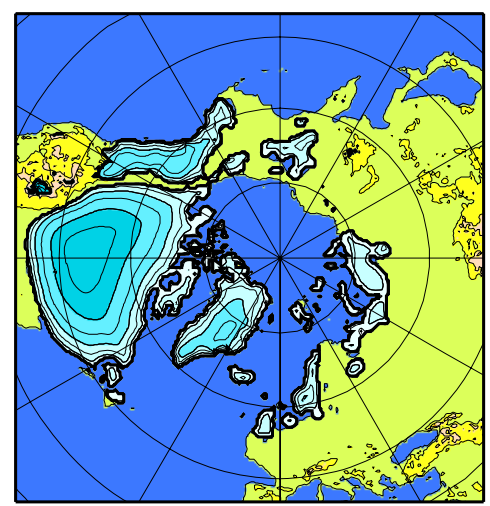

CCSR1

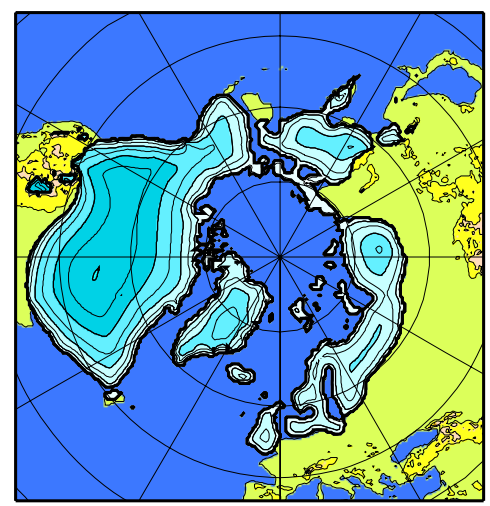

ECHAM3

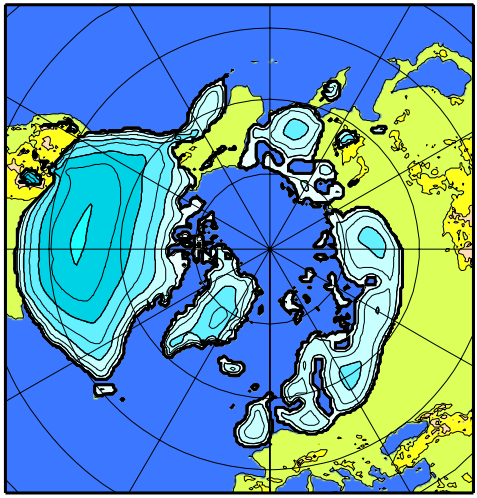

UGAMP

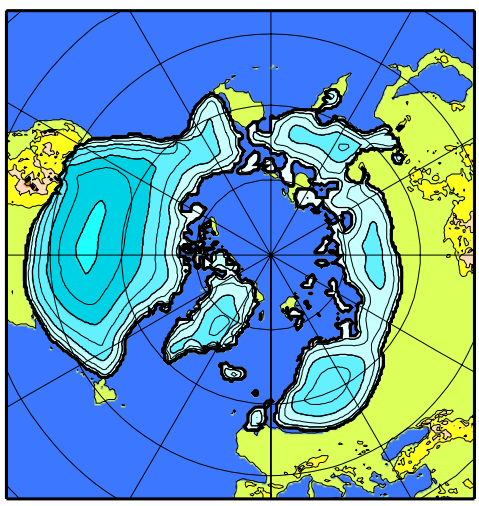

MRI2

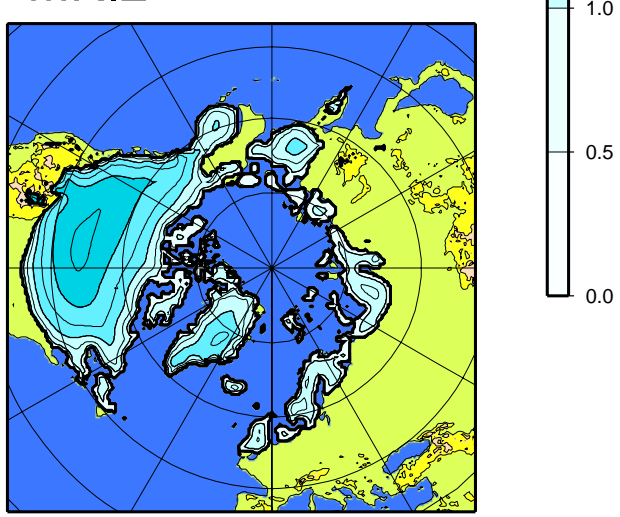

$18 \mathrm{kyr}$ BP

Fig. 6. Same as Fig. 4 for the $18 \mathrm{kyr}$ BP period which corresponds to the maximum ice volume.

$30{ }^{14} \mathrm{C}$ kyr BP (i.e. 29-34 kyr BP, after Bard et al. (2004)), in response to a new climatic deterioration to reach its maximum extent at around $15-14{ }^{14} \mathrm{C} \mathrm{kyr} \mathrm{BP} \mathrm{(i.e.} 16-18.5 \mathrm{kyr} \mathrm{BP}$, after INTCAL04 from Reimer et al. (2004)). Our modeling results are highly discordant from such a configuration.
First, the Cordilleran region remains glaciated throughout the simulated last glacial period whatever the choice of the forcing GCM, and starts to retreat synchronously with the Laurentide ice sheet. The other point of disagreement lies in a too large ice extent in Alaska. As reminded by Clague 


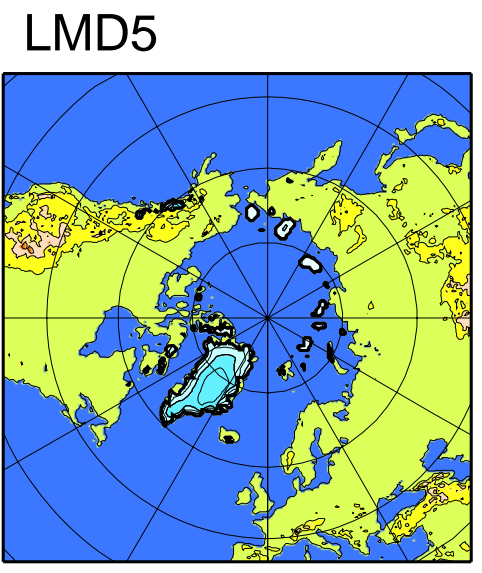

\section{GEN2}

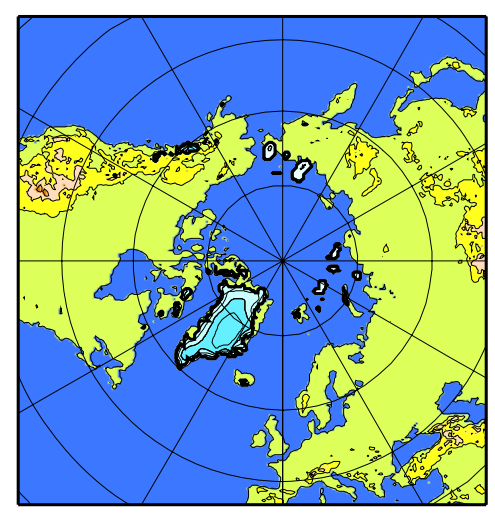

\section{CCSR1}

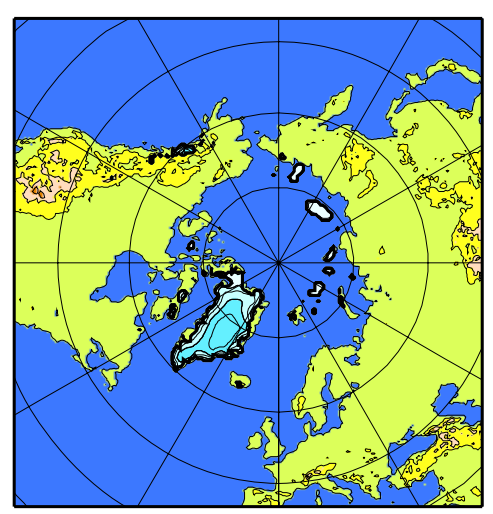

\section{ECHAM3}

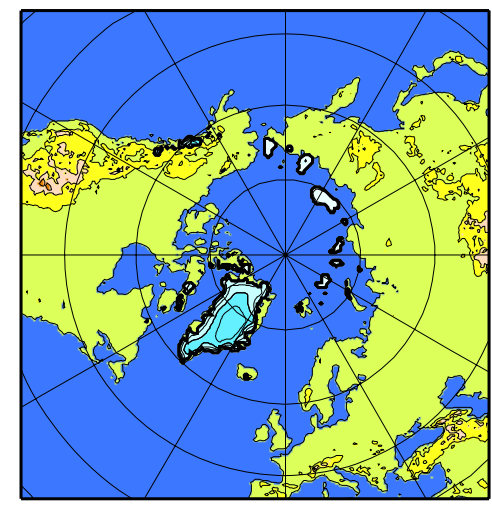

UGAMP

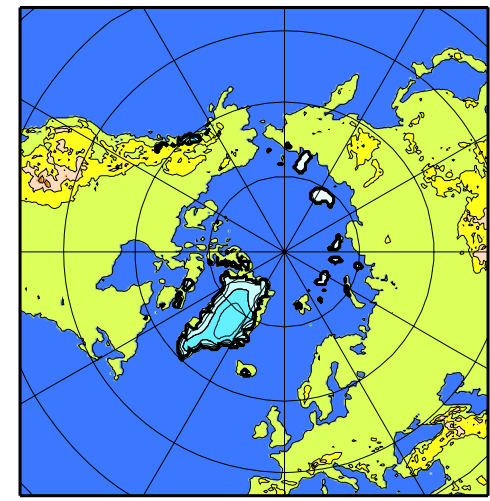

MRI2

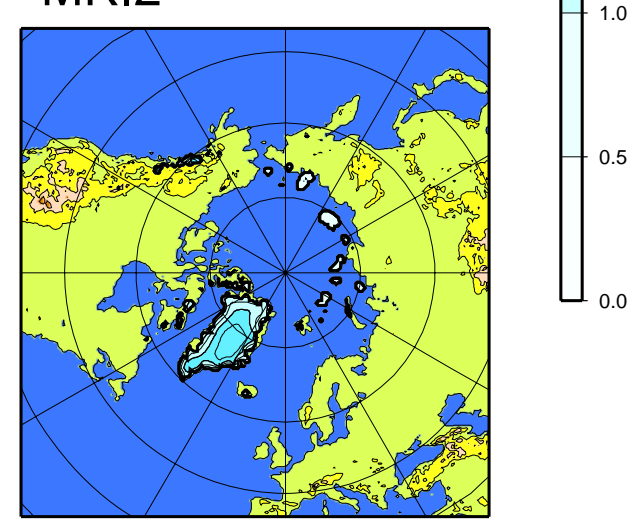

\section{Present-day}

Fig. 7. Same as Fig. 4 for the present-day period.

and James (2002), the Cordilleran ice sheet was only extended over the Southern part of this region and consisted of small ice fields and glaciers flowing towards the Pacific Ocean or the Yukon River (Mann and Hamilton, 1995). Consequently much of the Alaskan interior likely remained to be unglaciated throughout the last glacial cycle. In the present study, the use of CCSR1, UGAMP and even MRI2 and GENESIS2 probably overestimate the amount of ice over Alaska, whereas LMD5 and ECHAM3 are presumably in a better agreement with data. 
The last point which could be discussed is related to the coalescence of the Cordilleran and Laurentide ice sheets. There is no complete consensus about the junction or the separation of these ice sheets. According to Tarasov and Peltier (2004), a thick Keewatin dome, and therefore the attendant coalescence of at least the Northern half of the Cordillerean ice sheet with the Laurentide, is required to fit observations for present-day rates of uplift at Yellowknife. At present, other groups propose that the coalescence did not occur all along the north-south transect at the frontier between the Cordilleran and Laurentide ice sheets (see Dyke et al., 2002 for a detailed review), while Dyke et al. (2002) support the idea that they were fully coalescent at the LGM because it is difficult to conceive that the ice sheets were joined in some places and not in other. This is in agreement with the LGM ICE-4G reconstruction (Peltier, 1994) which does not reproduce a separation between the ice sheets (Fig. 2), although the ice thickness is smaller than in the adjacent regions. However, it is worth noting that the CordilleranLaurentide interface sector has no constraint, because this region has not been inundated in the past. The use of the GENESIS2 climatic outputs allows a disconnection between the ice sheets to be clearly simulated at the LGM (Fig. 6), due to the fact that at the frontier between Cordillera and Laurentide, simulated surface temperatures are warmer than in the surroundings. Other deviations from the ICE-4G reconstruction (Fig. 2) are observed in our LGM simulations. First, the southern margin is much too extended in some models (CCSR1, UGAMP and ECHAM3). Except for ECHAM3 and LMD5, the ice extent in Alaska is overestimated and the advance of ice in the Baffin Bay is not properly reproduced with the use of MRI2, GENESIS2 and LMD5, due partly to summer temperatures in this region warmer than those simulated by the three other models. Finally, the maximum ice thickness is not located at the same place as in ICE-4G.

\subsubsection{The Eurasian ice sheet}

The glaciation over the Eurasian continent starts with small ice caps formed over the Taimyr Peninsula and some Arctic islands (Figs. 3-4). This is in accordance with the recent review performed within the framework of the QUEEN project (Svendsen et al., 2004), but the inception is delayed compared to the most recent reconstruction of Lambeck et al. (2006) which is partly due to the fact that the model does not incorporate any treatment of the ice flow through iceshelves. The formation of ice is also simulated in the Norwegian mountains as early as $113 \mathrm{kyr}$ BP (Fig. 3) with all models except LMD5 because of a relatively high annual summer surface air temperature. By $112 \mathrm{kyr}$ BP (Fig. 4), the icecovered areas have significantly extended. The most rapid expansion of ice can be seen with ECHAM3 and UGAMP, and to a lesser extent with CCSR1, with significant amounts of ice east of the Taimyr Peninsula and close to Eastern Siberia. Although there is few data related to the early glacia- tion of Eurasia, there is no geological record indicating that there was ice in these latter regions (Vartanyan et al., 1995; Brigham-Grette, 2001). However, the presence of ice in Siberia could be a direct consequence of the albedo effect induced by the marine ice mass in the Arctic Ocean present in the LGM ICE-4G reconstruction (Fig. 2) near the Siberian coast and therefore imposed to the AGCMs as a boundary condition.

Around $90 \mathrm{kyr}$ BP the reconstruction of the limits of the Eurasian ice sheet provided by Svendsen et al. (2004) indicates that the ice was spread over Norway, the Barents-Kara Seas including the Svalbard, the Franz Josef islands and Novaya and Severnaya Zemlya, and extended eastward beyond the Taimyr Peninsula, covering also the Putorana Plateau. Among the different GCMs used in this study, the forcing from ECHAM3 presents the best agreement for this period (not shown) with this synthesis.

Around the early Middle Weichselian period (60$50 \mathrm{kyr}$ BP) the ice advanced over Finland, the Baltic Sea and the Kola Peninsula. In the Barents Sea, the ice sheet was more extended, while in the east, a much smaller area of Siberia is affected by the glaciation compared to the Early Weichselian period. None of the simulations performed in this study (Fig. 5) is in a perfect agreement with this reconstruction. The first point of disagreement concerns the too large expansion of the simulated ice sheet accross Eastern Siberia (CCSR1, MRI2, UGAMP and ECHAM3) while reconstructions indicate a retreat of the eastern part of the ice sheet around the Middle Weichselian period. A possible mechanism at the origin of this discrepancy could be linked to a reduction of precipitation over the Eastern part when the ice sheet over the Scandinavian region became huge enough. This mechanism would be fully similar to the one suggested by Clark and Bartlein (1995) to explain the glaciation scenario of the Cordilleran-Laurentide ice complex. Therefore, in the case of the Eurasian ice sheet, this "East-West" sequence cannot be reproduced with our approach. Another cause of the presence of ice in this region lies in the fact that the ICE-4G reconstruction extends too much eastward (Fig. 2). This enhances, via the albedo effect, the advance of ice in regions located East of the Taimyr Peninsula and also favours the growth of ice in Beringia, which is also due, as previously mentioned, to the marine ice complex produced by the ICE-4G reconstruction. Note that the Bering Strait looks open in the simulations performed with UGAMP, CCSR1 and ECHAM3 that have the highest sea-level drop (see Fig. 8a). This illustrates the isostatic effect: if there is a large amount of ice over Beringia or adjacent regions, the bedrock will deeply be depressed, and as a consequence the Bering Strait will remain open. Actually, this effect is balanced by the subsequent sea-level drop. However, this second effect is not displayed in the figures because the sea-level is not interactively computed in the model.

In the simulations carried out with LMD5 and GENESIS2, ice does not appear in Beringia, although the GCM are also 
run with the ICE-4G boundary condition. Therefore, in these runs, the albedo effect induced by an erroneous amount of ice in the Arctic Ocean is likely masked by another process which could be linked to the climate models themselves, such as a change in the planetary waves, which would lead in that case to warmer temperatures over Beringia. Another assumption is suggested by Krinner et al. (2006) which argue that the ice-free conditions in Northern Asia were favoured by strong glacial dust deposition over the seasonal snow cover in this region, thus enhancing snow melt by lowering the snow albedo. The second point of disagreement between our results and the reconstructions of the Eurasian ice sheet limits concerns the advance of ice over the Barents and the Kara Seas which is not reproduced in our simulations. This effect, which appears in all the simulations, is due to the absence of any explicit representation of the ice flow through the marine part of the ice sheets in the GREMLINS model. Although there is a parameterization which deals with the advance of ice into the sea, this advance is not rapid enough to properly reproduce the growth of the Barents-Kara Sea ice complex. The ice sheet simulated with the use of MRI2 does not penetrate southward enough, due to warm simulated summer surface air temperatures, especially to the South of the Scandinavian region, compared to those obtained with other GCMs. On the contrary, with the UGAMP model, the ice covering the Scandinavian region extends too much to the South in response to cold annual and summer temperatures added to a high precipitation ratio in this region. The ice coverage over Scandinavia is too small with LMD5 and GENESIS2 due to warmer surface air temperatures (Figs. 1a-b). However, both these models present the best agreement with the reconstruction of the Eastern ice-sheet limit. Finally, all models simulate ice over the British Isles, although they were unlikely to be glaciated during the Middle Weichselian period (Svendsen et al., 2004).

At the Last Glacial Maximum, the reconstruction of the ice limits is relatively well known. The Barents-Kara ice complex was strongly reduced and did not expand further east of Novaya Zemlya (Svendsen et al., 2004). None of the models used in the present study successfully simulate the recession of the Barents-Kara Sea ice sheet, and except for MRI2, the ice volume and the ice extent are larger compared to the Early Middle Weichselian period (Fig. 6). On the other hand, on the western side, the ice sheet advanced much more in the southwestern part, leading to a bridge between Scandinavia and the British Isles, not reproduced by GREMLINS whatever the GCM outputs used as climate forcing. However, these major drawbacks are due to the ICE-4G reconstruction itself which favours a huge ice sheet at the LGM over the Barents-Kara Seas region and, in which the junction between the European continent and the British Isles is not properly represented. Finally, as in the Middle Weichselian period, the ice coverage over Scandinavia remains insufficient in the simulations performed with LMD5 and GENESIS2.
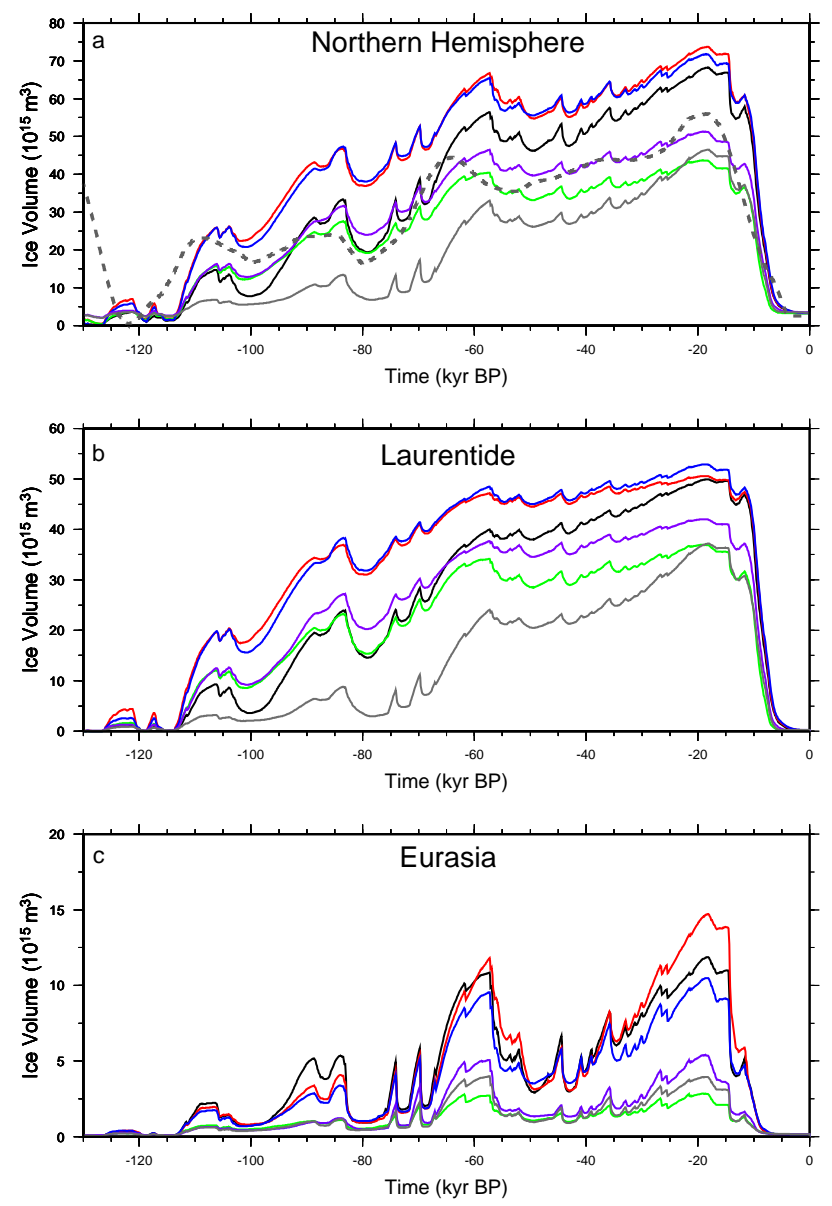

Fig. 8. Temporal evolution of the simulated ice volumes for the Northern Hemisphere (a) and for the North American (b) and Eurasian ice sheet (c). The different curves correspond to the six different AGCM: ECHAM3 (black line), UGAMP (red line), GENESIS2 (green line), CCSR1 (blue line), LMD5 (purple line), MRI2 (grey line). The dashed line represents the ice-equivalent sea-level contribution of the Northern Hemisphere (see text).

\subsection{Temporal evolution of the ice-sheet characteristics}

\subsubsection{The simulated Northern Hemisphere ice volumes}

The evolution of the simulated ice volumes throughout the last glacial cycle is displayed in Fig. 8 for the overall Northern Hemisphere and for the specific contributions of the past North American and Eurasian ice sheets. Each curve is related to one GCM forcing. The dashed line represents the Northern Hemisphere ice sheet contribution to sea-level variation relative to the present-day level. This curve is obtained by removing the Antarctic contribution to the sea-level reconstruction provided by (Bassinot et al., 1994) and converted in ice volume equivalent, and by adding the presentday contribution of Greenland $\left(\sim 2.6 \times 10^{15} \mathrm{~m}^{3}\right)$ to allow a direct comparison between the simulated ice volume and the sea-level derived from experimental data. The evolu- 

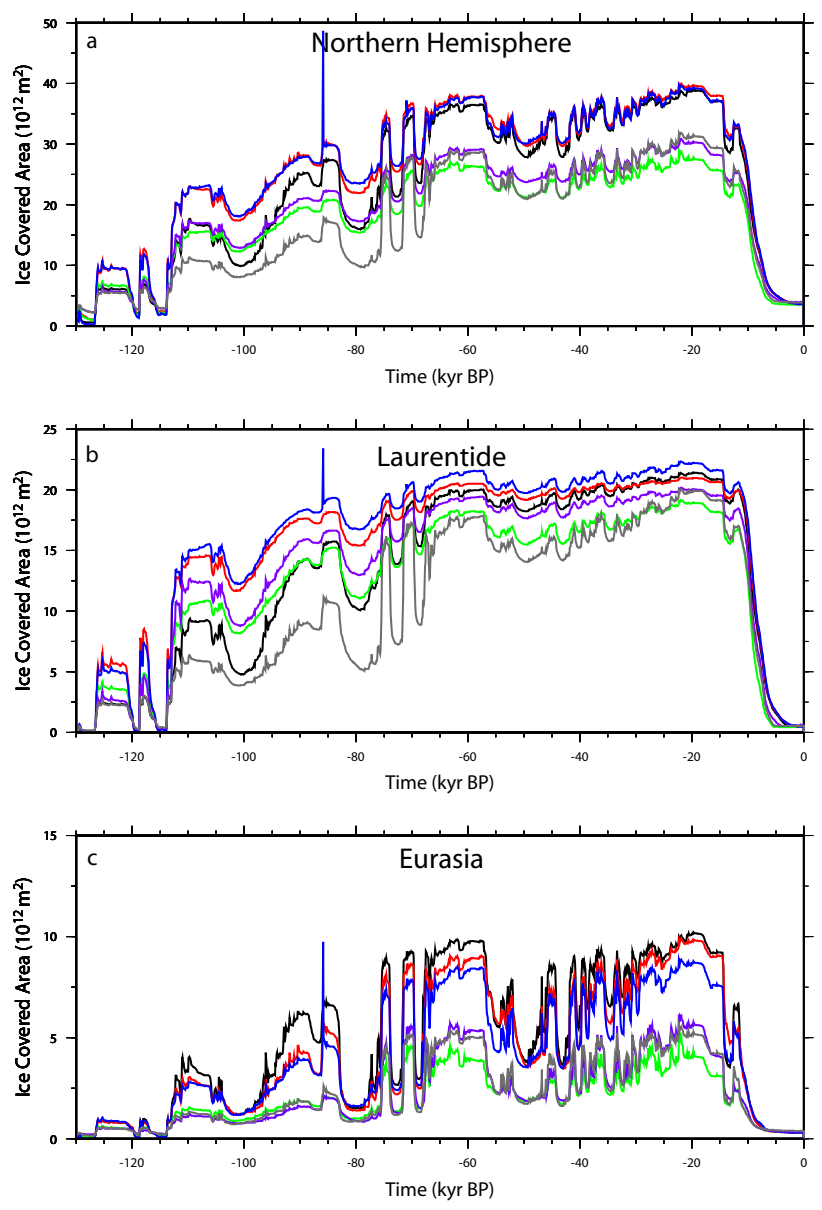

Fig. 9. Same as Fig. 2 but for the ice-covered area.

tion of the Antarctic ice volume throughout the last glacialinterglacial cycle is estimated with the GRISLI Antarctic icesheet model (Ritz et al., 2001), and the present-day Greenland contribution is estimated by averaging the results of the six PMIP-GREMLINS simulations. The conversion between sea-level and ice volume equivalent is made by assuming a constant oceanic area throughout the simulation (i.e. $\sim 3.6 \times 10^{14} \mathrm{~m}^{2}$ ).

The evolution of the ice covered area is represented in Fig. 9. Since it is controlled by the timing of the GRIP record, the temporal evolution of both ice volumes and icecovered-area is approximately the same for all the six simulations. Although, small ice caps are formed as early as $126 \mathrm{kyr}$ BP (Fig. 9), they are then subjected to phases of disappearance/appearance, and the initiation of the ice sheets really takes place at around $113 \mathrm{kyr} \mathrm{BP}$, as marked both in ice volume and ice-covered area signals (Figs. 8-9), as well as in the spatial distribution of the ice sheets (Figs. 34). The ice volume growth is slower than that of the ice surface. This confirms that the glacial inception is primarily characterized by a rapid extension of the ice due to the effect of the ice albedo which acts as an amplifier of the cooling mechanism and dominates the effect of accumulation which is rather responsible for the evolution of the ice thickness and hence of the ice volume. These conclusions were previously reached by Kageyama et al. (2004). However, as previously mentioned to interpret the rapid expansion of ice around $112 \mathrm{kyr}$ BP (Fig. 4), the albedo effect is overestimated due to the use of LGM climate snapshots. The period following the ice-sheet nucleation is characterized by three main phases of major ice sheet growth punctuated by shorter episodes of ice retreat. The phases of ice volume increase occur between 113 and $106.2 \mathrm{kyr}$ BP, 100.2 and $83.5 \mathrm{kyr} \mathrm{BP}$ and between 79.2 and $57.3 \mathrm{kyr} \mathrm{BP}$, where a full glacial state takes place (see also Fig. 5). At $57.3 \mathrm{kyr}$ BP the Northern Hemisphere ice volume is only $10 \%$ lower than the last glacial maximum value, located at $18.2 \mathrm{kyr} \mathrm{BP}$, except for ECHAM3 (83\% of the LGM ice volume) and MRI2 (71\%). In the same way, at $57.3 \mathrm{kyr} \mathrm{BP}$, the glaciated area is between 92 and $97 \%$ that obtained at the time of the LGM, depending on the GCM. After $18.2 \mathrm{kyr}$ BP, the ice volume slightly decreases until $16.6 \mathrm{kyr}$ BP. It then remains approximately stable until about $15.0 \mathrm{kyr} \mathrm{BP}$ where the main phase of the deglaciation is triggered. As described in (Charbit et al., 2002), this phase is correlated with a warming event observed in the GRIP record. A slight increase of the ice volume is then observed and corresponds to the YoungerDryas. The deglaciation of the North American ice sheet is achieved approximately between 5 and $2 \mathrm{kyr}$ BP, depending on the GCM, whereas for all models the complete retreat of Fennoscandia occurs between 6 and $5 \mathrm{kyr}$ BP. Therefore, the simulated deglaciation is well delayed compared to that inferred from the GRIP record and eustatic sea-level rise data (e.g., Bard et al., 1996b).

In spite of the common features mentioned above, some clear differences appear between the results of the different runs. The most striking feature is related to the amplitude of the difference between glacial and interglacial ice volume (or ice coverage area) from one GCM to the other, and more generally, between phases of growth and retreat of the ice sheet. Figure 8 clearly shows that the highest simulated ice volumes are obtained by using the UGAMP and CCSR 1 outputs as climate forcing. In contrast, the use of MRI2 produces the lowest ice volume throughout the simulation except at the LGM because of the contribution of the Eurasian ice sheet. While LMD5 and GENESIS2 lead to "intermediate" ice volumes, the case of ECHAM3 is particularly interesting. In fact during the early phase of glacial inception (between 113 and $106 \mathrm{kyr} \mathrm{BP}$ ), the simulated ice volume is of the same order of magnitude than those obtained with LMD5 and GENESIS2. However, after $70 \mathrm{kyr} \mathrm{BP}$, it becomes greater (it increases by $\sim 42 \%$ between 70 and $60 \mathrm{kyr} \mathrm{BP}$ ) and reaches some values close to those obtained with CCSR1 and UGAMP. In the same way, though the ice volume simulated with the MRI2 climate remains at a low level, especially prior to $70 \mathrm{ka}$, it presents the most significant variations during the full glacial 
period : between 70 and $60 \mathrm{kyr} \mathrm{BP}$, the amplitude increases by $\sim 72 \%$ and by $\sim 57 \%$ between $60 \mathrm{ka}$ and the Last Glacial Maximum. As an example, this can be compared to the ice volume curves obtained with LMD5 and GENESIS2 which respectively increase by $14 \%$ and $10 \%$ during the same period, or with CCSR1 and UGAMP (14 and 15\% increase respectively).

3.2.2 Links between ice volumes, climate forcing and spatial distribution

The same kind of differences also appears in the ice volume curves relative to the American or the Fennoscandian ice sheets. These differences can be interpreted in terms of climate forcing and spatial distribution of the ice sheets.

For the Laurentide ice sheet, the largest ice volumes are obtained with UGAMP and CCSR1 which provide the coldest temperatures over the Canadian region (Fig. 1): the changes in summer surface air temperature between the LGM and the present-day periods can be as high as $-40^{\circ} \mathrm{C}$ for both models over a great part of the ice complex (Fig. 1b). The precipitation ratio between the LGM and the present-day climates simulated by UGAMP is rather small on the western and eastern parts of the ice sheet, but can reach a value as high as 2.5 in some specific locations such as the wind exposed slope of the Rocky Mountains or the southern margin of the Keewatin region (Fig. 1c). Among the GCMs used in this study, CCSR 1 is the model which simulates the highest LGM/CTRL precipitation ratio over the North American ice complex. The LMD5 model provides summer temperatures as cold as those given by UGAMP and CCSR1 but the LGM precipitation ratio between the LGM and the present-day periods does not exceed 0.6. Until $65 \mathrm{kyr} \mathrm{BP}$, the simulated ice volume obtained with ECHAM3 is below that obtained with the LMD5 climate, and becomes greater after this period (see previous section). This can be explained by the fact that, although the ECHAM3 precipitation ratio between past and present is high over the southern part of the ice complex ( $>1.6)$, the simulated summer temperatures are widely higher than the LMD5 ones (Fig. 1b). Since glacial inception is primary driven by the temperature signal the ice volume remains at a low level before the second phase of inception is reached, that is before the full glacial period. Moreover, since the ice sheet is located at low latitudes (Fig. 4) it is sensitive to any change in temperature. At $65 \mathrm{kyr} \mathrm{BP}$ an abrupt decrease in the temperature reconstructed at the surface of the ice sheet is observed in the GRIP signal (Dansgaard et al., 1993). This decrease in the temperature signal added to the high precipitation value leads to a significant increase in the ice volume. This change in the evolution of the ice volume signal is not observed with LMD5 because the precipitation ratio is lower over the ice-sheet location. The situation is different for the comparison between GENESIS2 and LMD5: the GENESIS2 higher summer temperatures combined with higher precipitation rates lead to an ice volume fully comparable to that resulting from the LMD5 forcing climate until $95 \mathrm{ka}$, but widely below it after this period. This can be explained by the surface temperatures at the frontier between the Laurentide and the Cordilleran ice sheets which are higher than over the other regions of Canada. This prevents both ice sheets from coalescing, therefore limiting the increase of the ice volume (see Sect. 3.1). The lowest ice volume during the entire simulation is obtained by forcing GREMLINS with MRI2. The magnitude of the MRI2 precipitation ratio is between 0.4 and 0.6 , but the temperatures are warmer than the LMD5 ones (not below $-25^{\circ} \mathrm{C}$ in summer and $-20^{\circ} \mathrm{C}$ for the annual mean).

The ice volume curves relative to the Eurasian ice sheet can be split in two groups: UGAMP, ECHAM3 and CCSR1 on one hand and LMD5, MRI2 and GENESIS2 on the other. The first group of models is characterized by low annual temperatures (i.e. the variation between past and present is $-40^{\circ} \mathrm{C}$ over a large part of the Fennoscandian area, especially for ECHAM3 and CCSR1). The precipitation ratio is relatively small for ECHAM3 and UGAMP (0.2-0.4 North of Scandinavia), but comparable with that of MRI2 for CCSR1. Between 100 and $85 \mathrm{kyr} \mathrm{BP}$, the ice volume simulated with ECHAM3 is greater than that obtained with UGAMP and CCSR1, due to the fact that ECHAM3 simulates the lowest summer surface air temperatures. This acts in favour of glaciation especially during the inception period. After $60 \mathrm{kyr} \mathrm{BP}$, that is, during the full glacial period, and until about $10 \mathrm{kyr}$ BP the highest volume is obtained with UGAMP which simulates a cold tongue extended far to the Northeast of Scandinavia. The second group of models is characterized by slightly higher precipitation ratios and smaller changes in summer temperatures (between -25 and $-20^{\circ} \mathrm{C}$ for LMD5 and -20 and $-15^{\circ} \mathrm{C}$ for MRI2 and GENESIS2), and also by the fact that the regions where the coldest temperatures are observed are less extended compared to temperature patterns provided by the first group of models, suggesting that the evolution of the Eurasian ice sheet is rather sensitive to the temperature than to precipitation.

This discussion highlights the strong link between icesheet inception in some specific regions, and thus their further development, and the overlying temperature combined with the accumulation rate. Table 2 reports the mean climate (in terms of mean temperature and mean precipitation ratio). Although these mean values cannot account for the ice history in given locations, they schematically illustrate why some climate models lead to higher volumes than others. They also underline the dominant role of summer temperature compared to the annual temperature.

\subsubsection{Model-model and model-data comparisons}

At the LGM (i.e. $18.2 \mathrm{kyr}$ BP) the Northern Hemisphere simulated ice volume is between 43.6 and $73.7 \times 10^{15} \mathrm{~m}^{3}$. This range can be compared to that provided by Milne et al. (2002) obtained with a radial viscoelastic ice-Earth 
Table 2. Mean climate forcing. Simulated mean summer and annual temperatures over the North American ice sheet (Tjja_NAIS and Tann_NAIS) and the Fennoscandian ice sheet (Tjja_FIS and Tann_FIS) and simulated mean annual precipitation ratio between the LGM and present $\left(P_{21 k} / P_{\text {ctrl }}\right)$.

\begin{tabular}{lcccccc}
\hline Models & Tjja_NAIS $\left({ }^{\circ} \mathrm{C}\right)$ & Tann_NAIS $\left({ }^{\circ} \mathrm{C}\right)$ & $\left(\mathrm{P}_{21 k} / \mathrm{P}_{\mathrm{ctrl}}\right) \_$NAIS & Tjja_FIS $\left({ }^{\circ} \mathrm{C}\right)$ & Tann_FIS $\left({ }^{\circ} \mathrm{C}\right)$ & $\left(P_{21 k} / P_{\mathrm{ctrl}}\right) \_$FIS \\
\hline ECHAM3 & -13.7 & -12.0 & 0.84 & -15.5 & -20.0 & 0.62 \\
UGAMP & -14.6 & -12.7 & 0.81 & -13.4 & -17.0 & 0.63 \\
CCSR1 & -15.6 & -15.0 & 0.87 & -13.6 & -19.0 & 0.72 \\
GENESI2 & -12.9 & -13.2 & 0.84 & -9.6 & -16.8 & 0.49 \\
LMD5 & -15.9 & -11.7 & 0.69 & -11.0 & -12.9 & 0.54 \\
MRI2 & -13.2 & -10.7 & 0.72 & -9.1 & -13.1 & 0.55 \\
\hline
\end{tabular}

model used to predict the sea-level change from the LGM to present in four far-field sites, and based on a revised theoretical formalism incorporating the Earth rotational effects on sea level, a time-dependent shoreline geometry and an accurate treatment of sea-level change in regions of ice retreat. By de-constructing the spatially uniform versus the spatially varying signals of sea-level change and by isolating the contributions of ice loading, ocean loading and rotational effects they concluded that the meltwater contribution dominates the far-field sea-level change signal. This meltwater component can be explicitly (Flemming et al., 1998; Yokoyama et al., 2000) or implicitly (Peltier, 1994) estimated by correcting the observations for the contribution of the glacial isostatic adjustment. Based on two contrasting interpretations of Barbados coral data, they obtained estimates of the grounded ice volume ranging from 43.5 to $51.0 \times 10^{15} \mathrm{~m}^{3}$. These values are fully compatible with the ice volumes obtained with GENESIS2 $\left(43.6 \times 10^{15} \mathrm{~m}^{3}\right)$, MRI2 $\left(46.5 \times 10^{15} \mathrm{~m}^{3}\right)$ and LMD5 $\left(51.2 \times 10^{15} \mathrm{~m}^{3}\right)$ outputs, and suggest that ECHAM3 $\left(68.2 \times 10^{15} \mathrm{~m}^{3}\right)$, UGAMP $\left(73.7 \times 10^{15} \mathrm{~m}^{3}\right)$ and CCSR $1\left(71.7 \times 10^{15} \mathrm{~m}^{3}\right)$ cannot provide a realistic climate forcing at the LGM. This is confirmed by the comparison between the sea-level curve and the simulated ice volumes.

To go a step further, it is also interesting to examine which amount of ice is distributed over the North American and the Eurasian ice sheets at the LGM (i.e. $18 \mathrm{kyr} \mathrm{BP}$ in the simulations). The contributions of both ice sheets range respectively from 36.9 to $52.9 \times 10^{15} \mathrm{~m}^{3}(36.6-$ $52.4 \times 10^{15} \mathrm{~m}^{3}$ at $21 \mathrm{kyr}$ BP) and from 2.8 to $14.7 \times 10^{15} \mathrm{~m}^{3}$ $\left(2.7-13.5 \times 10^{15} \mathrm{~m}^{3}\right.$ at $21 \mathrm{kyr}$ BP). For the North American ice sheet, our results are neither compatible with the ICE4G ice-sheet reconstruction (Peltier, 1994) used as boundary condition for the AGCM LGM runs, nor with the more recent ICE-5G topography (Peltier, 2004). Both reconstructions provide ice volume values which are well below our lower limit $\left(24.5 \times 10^{15} \mathrm{~m}^{3}\right.$ and $34.3 \times 10^{15} \mathrm{~m}^{3}$ for ICE-4G and ICE-5G respectively). The reconstructed Fennoscandian ice volume is $8.7 \times 10^{15} \mathrm{~m}^{3}$ for ICE- $4 \mathrm{G}$ and $9 \times 10^{15} \mathrm{~m}^{3}$ for ICE-5G. These reconstructions lie in the range of our set of simulations. However, compared to these reconstructions, the first group of models $\left(2.8 \times 10^{15} \mathrm{~m}^{3}-5.6 \times 10^{15} \mathrm{~m}^{3}\right)$ underestimates the ice volume, while the ice volumes obtained with the second group $\left(10.5 \times 10^{15} \mathrm{~m}^{3}-14.7 \times 10^{15} \mathrm{~m}^{3}\right)$ are overestimated.

To quantify the uncertainties associated with glaciological reconstructions of the North American ice sheet, Marshall et al. (2002) carried out numerous experiments with a 3-D thermo-mechanical model prescribing different climatic conditions and different glaciological and isostatic treatments. Considering only the simulations which gave a reasonable areal extent of the ice sheet, this provided values ranging from 28.5 to $38.9 \times 10^{15} \mathrm{~m}^{3}$, only in accordance with the modeling results obtained with GENESIS2 $\left(36.9 \times 10^{15} \mathrm{~m}^{3}\right)$ and MRI2 $\left(37.2 \times 10^{15} \mathrm{~m}^{3}\right)$. Using an ice-sheet model, forced by global sea-level and solar insolation changes, Siegert et al. $(1999,2001)$ modeled the Eurasian ice sheet through the Late Weichselian period. They adjusted their "model's climate forcing function" to produce a minimum and a maximum ice sheet reconstruction compatible with geological and oceanographic datasets. The simulated LGM ice volumes are respectively at around 5 and $8 \times 10^{15} \mathrm{~m}^{3}$, in agreement with what we find with LMD5 only $\left(5.4 \times 10^{15} \mathrm{~m}^{3}\right)$ : the results obtained with GENESIS2 and MRI2 are well below the minimum ice volume, whereas UGAMP $\left(14.7 \times 10^{15} \mathrm{~m}^{3}\right)$, CCSR $1\left(10.5 \times 10^{15} \mathrm{~m}^{3}\right)$ and ECHAM3 $\left(11.9 \times 10^{15} \mathrm{~m}^{3}\right)$ provide values which widely exceed those obtained with the maximum model.

The comparison between our results and other modeling studies or sea-level data suggests that most of the simulations presented in this study overestimate the ice volume throughout the last glacial cycle. This can be due to subgrid processes, not represented in the ice-sheet model, which may have had accelerated the ice flow, such as the flow of several large glaciers which accelerates the overall ice discharge, as it has been demonstrated with recent measurements for the Greenland ice sheet (Dowdeswell, 2006; Rignot and Kanagaratnam, 2006). Morover, it is also worth reminding that fast flow due to ice streams or basal-till deformation is not accounted for in GREMLINS. The Antarctic 
Table 3. Simulated and reconstructed LGM ice volumes. Simulated maximum ice volumes (at $18.2 \mathrm{kyr}$ BP) corresponding to each GCM compared to reconstructed LGM (21 kyr BP) ice volumes from ICE-4G (Peltier, 1994), ICE-5G (Peltier, 2004) and from sea-level data. These values are given for the entire Northern Hemisphere $\left(V_{\mathrm{NH}}\right)$, the North American ice sheet $\left(V_{\mathrm{NAIS}}\right)$, the Fennoscandian ice sheet $\left(V_{\mathrm{FIS}}\right)$. Column 5 gives the simulated LGM ice volume in the Eastern Siberian region $\left(V_{\mathrm{Sib}}\right)$. Column 6 gives the Northern Hemisphere LGM ice volume corrected for fast flow. This correction is made by removing $8.0 \times 10^{15} \mathrm{~m}^{3}$ (see text) from the Northern Hemisphere ice volume. Column 7 gives the Northern Hemisphere LGM ice volume after correction for fast flow and for the Eastern Siberian ice volume.

\begin{tabular}{lcccccc}
\hline $\begin{array}{l}\text { Models \& } \\
\text { Reconstructions }\end{array}$ & $\begin{array}{c}V_{\mathrm{NH}} \\
\left(\times 10^{15} \mathrm{~m}^{3}\right)\end{array}$ & $\begin{array}{c}V_{\mathrm{NAIS}} \\
\left(\times 10^{15} \mathrm{~m}^{3}\right)\end{array}$ & $\begin{array}{c}V_{\mathrm{FIS}} \\
\left(\times 10^{15} \mathrm{~m}^{3}\right)\end{array}$ & $\begin{array}{c}V_{\mathrm{Sib}} \\
\left(\times 10^{15} \mathrm{~m}^{3}\right)\end{array}$ & $\begin{array}{c}V_{\mathrm{NH}}-\text { fast flow } \\
\left(\times 10^{15} \mathrm{~m}^{3}\right)\end{array}$ & $\begin{array}{c}V_{\mathrm{NH}}-\text { fast flow }-V_{\mathrm{Sib}} \\
\left(\times 10^{15} \mathrm{~m}^{3}\right)\end{array}$ \\
\hline ECHAM3 & 68.1 & 49.9 & 11.8 & 2.0 & 60.1 & 58.1 \\
UGAMP & 73.6 & 50.5 & 14.7 & 3.8 & 65.6 & 61.8 \\
GENESIS2 & 43.4 & 36.8 & 2.8 & 0.5 & 35.4 & 34.9 \\
CCSR1 & 71.5 & 52.8 & 10.4 & 3.4 & 63.5 & 60.1 \\
LMD5 & 51.0 & 41.9 & 5.2 & 0.08 & 43.0 & 32.9 \\
MRI2 & 46.5 & 37.2 & 3.9 & 1.5 & 38.5 & 37.0 \\
ICE-4G & 40.0 & 24.5 & 8.7 & & & \\
ICE-5G & 49.8 & 34.3 & 9.0 & & & \\
Ice-equivalent sea-level & 56.1 & & & & & \\
$\left(\times 10^{15} \mathrm{~m}^{3}\right)$ & & & & & & \\
\hline
\end{tabular}

ice-sheet model, GRISLI, (Ritz et al., 2001), has recently been applied to the Northern Hemisphere (Peyaud, 2006). This model relies on the same equations than GREMLINS for the grounded ice, but it also accounts for the flow through ice - shelves, computes dynamically the grounded ice migration and detects the ice stream zone where the flow is considerably accelerated. Using this latter model, Peyaud (2006) performed simulations of ice sheets over the last glacialinterglacial cycle. The forcing climate relies on a pertubative method of the present-day climate, and the anomalies of climatic fields between glacial and interglacial periods and used to force GRISLI are interpolated through time using the GRIP-based $\delta^{18} \mathrm{O}$ index. These anomalies are not computed by GCMs but are deduced from an inverse method and are constrained by ice margin limits consistent with geological data. Sensitivity experiments to parameters which control the water drainage efficiency have been carried out. The difference of LGM ice volumes between the baseline experiment (which is equivalent to a grounded ice-only experiment in which no streaming occurs, and thus fully consistent with a GREMLINS experiment) and the most dynamic experiment is about $8.0 \times 10^{15} \mathrm{~m}^{3}$. This comparison allows the impact of ice stream flow to be evaluated. As an example the highest LGM ice volumes are obtained in the present study with the UGAMP and CCSR1 models $\left(73.6 \times 10^{15} \mathrm{~m}^{3}\right.$ and $71.5 \times 10^{15} \mathrm{~m}^{3}$ respectively). Accounting for streaming could lower these values to $65.6 \times 10^{15} \mathrm{~m}^{3}$ and $63.5 \times 10^{15} \mathrm{~m}^{3}$ respectively. Moreover, the choice of too high lapse rate values (Marshall et al., 2006) could lead to an overestimation of the ice volumes throughout the simulation. However, this would also affect the ice volumes simulated with the use of LMD5, MRI2 and GENESIS2, and not only those forced with UGAMP, CCSR1 and ECHAM3.
In the Eurasian sector, the discrepancies between simulated ice sheets and geological data could also come from the absence of the ice-shelf dynamics in GREMLINS (Peyaud, 2006) and from shortcomings in the ICE-4G reconstruction, as already mentioned. If the amount of Eastern Siberian ice is removed (geological data show that this region has never been ice-covered), the UGAMP and CCSR1 ice volumes are respectively $61.8 \times 10^{15} \mathrm{~m}^{3}$ and $60.1 \times 10^{15} \mathrm{~m}^{3}$, well above the value of $56.1 \times 10^{15} \mathrm{~m}^{3}$ corresponding to the sea-level converted into ice volume. This computation has been performed for all the GCMs used in the present study and the results are reported in Table 3. The use of the LMD5 model provides the most compatible value with the ICE-4G LGM value. The ECHAM3 model leads to a value close to the sealevel equivalent ice volume value. UGAMP and CCSR1 lead to too high volumes, even after corrections for strong sliding and Siberian ice volume, whereas, GENESIS2 and MRI2 ice volumes are significantly too small. However, these volume corrections partly rely on the correction of streaming (and set to its maximum value of $8.0 \times 10^{15} \mathrm{~m}^{3}$ ). To go thoroughly we need to account for the deformation of sediments which is responsible for a great part of the ice streams flow. Moreover, the lack of any fast flow treatment may also be at the origin of our delayed deglaciation. This demonstrates that an adequate representation of fast flow processes is of great importance to test the impact of sediment deformation to improve our simulations. This question will be addressed in a future paper devoted to same kind of study but with the PMIP2 AO-GCMs, run with the updated ICE-5G reconstruction at the LGM. These new runs will force the new GRISLINorth model. 


\section{Conclusions}

The climatic outputs from six PMIP-AGCMs have been used to force a 3-D thermo-mechanical ice-sheet model. This study reveals some great differences from one simulation to the other related both to the simulated temporal evolution of the ice volumes and ice-covered area and to the shape and spatial distribution of the ice sheets. The differences related to the evolution of the ice volumes can be partly directly interpreted in terms of climate forcing. Moreover, these differences also depend on the location of primary ice sheets which is, by the way, directly influenced by the climate itself. As an example, ice masses located at low latitudes in the early phase of glaciation are more sensitive to a temperature variation than a higher latitude ice sheet.

The comparison of our simulated ice sheets with geological and sea-level data highlights the importance of some major ice-climate feedbacks and raises the question of to which extent this kind of approach enables to test the ability of GCMs to simulate a climate leading to ice sheets compatible with available geological and geomorphological reconstructions. The differences between observations and simulations may come from i) the method of the climatic index, which may induce artifacts because the climatic variations during the last glacial-interglacial cycle are unlikely to be the same than those recorded at the GRIP site, ii) the choice of the vertical lapse rates which may overestimate the ice volumes if they are set to too high values, iii) the climate models or lacking processes in the ice-sheet models, iv) the-ICE-4G reconstruction: this work highlights the importance of having an accurate ice-sheet boundary condition for paleo-intercomparisons of GCMs. Actually, none of the simulations presented in this study is able to reproduce ice sheets in full agreement with observations.

The main points of disagreement concern:

1. The location of sites of primary inception which can directly be attributed to the climate forcing. For the Eurasian ice sheet, the Taimyr Peninsula is reasonably glaciated. However, observations indicate that the regions of ice-sheet inception in North America were those bordering the Eastern coast (Baffin Island and Quebec-Labrador sector) as well as the uplands of Northeastern Keewatin, which is not perfectly reproduced in the simulations.

2. The chronology of the simulated glaciation of the Rocky Mountains region which starts to be glaciated as early as $113 \mathrm{kyr} \mathrm{BP}$, while according to data, the Cordilleran ice sheet does not appear to have developed before $75 \mathrm{kyr}$ BP when the Laurentide ice sheet was high enough to induce a displacement of the jet stream. This sequence of events cannot be properly reproduced with our approach due to the absence of any ice-sheet feedback on the atmospheric circulation. Moreover, the use of LGM climate snapshots in the climate forcing overestimates the albedo effect throughout the simulation in regions covered by snow at the LGM, and, hence, accelerates the glaciation process. Subsequently, the advance of ice in Alaska is probably favored, via the artifact albedo effect, by the early glaciation of the Cordilleran ice sheet.

3. The absence of a multi-domed ice sheet which, according to Tarasov and Peltier (2004) likely results from the lack of representation of fast flow due to basal-till deformation.

4. The presence of ice in Siberia, which is not due to the absence of any representation of the feedback processes of the ice sheets on climate, since Siberia has remained unglaciated throughout the last glacial-interglacial cycle. In fact, the glaciation of the Siberian region is probably linked to the cold temperatures simulated by the climate models in response to the erroneous amount of ice provided by the LGM ICE-4G reconstruction (Peltier, 1994).

5. The too large eastward expansion of the Eurasian ice sheet around the Middle Weichselian period due partly to the ICE-4G reconstruction and to the fact that our approach is not able to reproduce a reduction of precipitation in the Eastern part, concomitant with the growth of ice over the Scandinavian region, nor the reduction of snow albedo due to dust deposition in Northern Asia during glacial times (Krinner et al., 2006).

6. The insufficient penetration of the Barents-Kara sea ice sheet into the sea, which is due to the absence in the GREMLINS model of any explicit representation of the ice flow through the ice-shelves (Peyaud, 2006; Lambeck et al., 2006).

7. The extent of the Scandinavian ice sheet: very few models succeed in simulating a reasonable amount ice over Fennoscandia (except the simulations carried out with ECHAM3 and UGAMP). This can be analyzed in terms of mean summer temperature and of a deficit of precipitation in the north leading to an insufficient northward expansion of the ice sheet. This raises the question of the sensitivity of the ice-sheet model to the climate forcing.

This study clearly demonstrates the great sensitivity of the ice sheets to the climate forcing. The great variability in the simulated climates used in the present study induces large differences in simulated ice sheets. Moreover, owing to the fact that some ice-climate feedbacks cannot be accounted for with this kind of approach, the magnitude of the climatic impacts on the ice sheet evolution are likely to be poorly estimated. 
The deviations of our simulations from geological data are partly due to an overestimation of the albedo effect in the climate simulations due to shortcomings in the ICE- $4 \mathrm{G}$ reconstruction. Therefore, it should be interesting to carry out the same kind of experiments with models used within the framework of the second phase of the PMIP project (PMIP2). On one hand these GCMs are coupled ocean-atmosphere models, in which the SSTs (Kageyama et al., 2006) appear to be more realistic than the CLIMAP ones used in PMIP1; on the other hand the LGM runs are performed with the upto-date ICE-5G reconstruction, which is a revised version of the ICE-4G model. This would allow the impact of the initial conditions to be tested. Moreover, these simulations will be performed with a new version of the Northern Hemisphere ice-sheet model which will include an explicit representation of the ice flow through ice shelves as well as streaming and basal-till deformation. Hence, by reducing the number of shortcomings in this kind of approach, it will be easier to attribute a kind of evaluation criteria of the PMIP2 model results which will appear in the next IPCC report.

Acknowledgements. We acknowledge all PMIP members. We also benefited from fruitful discussions with scientists participating to the MOTIF project. Thanks are also due to J.-Y. Peterschmitt for technical support and for providing PMIP database and PMIP and MOTIF websites (http://www-lsce.cea.fr/pmip, http://www-lsce.cea.fr/motif). Moreover, we are very grateful to Lev Tarasov and to an anonymous reviewer for their constructive comments which helped us improve the manuscript.

Edited by: M.-F. Loutre

\section{References}

Adler, R. F., Susskind, J., Huffman, G. J., Bolvin, D., Nelkin, E., Chang, A., Ferraro, R., Gruber, A., Xie, P.-P., Janowiak, J., Rudolf, B., Schneider, U., Curtis, S., and Arkin, P.: The Version2 Global Precipitation Climatology Project (GPCP) Monthly Precipitation Analysis (1979-Present), J. Hydrometeorol., 4(6), 1147-1167, 2003.

Alexander, R. C. and Mobley, R. L.: Monthly average sea surface temperatures and ice pack limits on a 1 global grid, Mon. Wea. Rev., 104, 143-148, 1976.

Andersen, K. K., Azuma, N., Barnola, J.-M., Bigler, M., Biscaye, P., Caillon, N., Chappellaz, J., Clausen, H. B., Dahl-Jensen, D., Fischer, H., et al.: High-resolution record of Northern Hemisphere climate extending into the last interglacial period, Nature, 431, 147-151, 2004.

Andrews, J. T. and Barry, R. G.: Glacial inception and disintegration during the last glaciation, Ann. Rev. Earth Planet. Sci., 6, 205-228, 1978.

Bamber, J. L., Layberry, R. L., and Gogenini, S. P.: A new ice thickness and bed data set for the Greenland ice sheet. 1. Measurement, data reduction and errors, J. Geophys. Res., 106(D24), 33 773-33 780, 2001.
Bard, E., Hamelin, B., and Fairbanks, R. B.: U-Th ages obtained by mass spectrometry in corals from Barbados: sea level during the past 130,000 years, Nature, 346, 456-458, 1990.

Bard, E., Jouannic, C., Hamelin, B., Pirazzoli, P., Arnold, M., Faure, G., Sumosusastro, P., and Syaefudin: Pleistocene sea levels and tectonic uplift based on dating of corals from Sumba Island, Indonesia, Geophys. Res. Lett., 23(12), 1473-1476, 1996a.

Bard, E., Hamelin, B., Arnold, A., Montaggioni, L., Cabioch, G., Faure, G., and Rougerie, F.: Deglacial sea-level record from Tahiti corals and the timing of global meltwater discharge, Nature, 382, 241-244, 1996b.

Bard, E., Rostek, F., and Ménot-Combes, G.: A better radiocarbon clock, Science, 303, 178-179, 2004.

Bassinot, F., Labeyrie, L. D., Vincent, E., Quidelleur, X., Shackleton, N. J., and Lancelot, Y.: The astronomical theory of climate and the age of the Brunhes-Matuyama magnetic reversal, Earth Planet. Sci. Lett., 126, 91-108, 1994.

Berger, A.: Long-term variations of daily insolation and quaternary climatic changes, J. Atmos. Sci., 35, 2362-2367, 1978.

Bintanja, R., van de Wal, R. S. W., and Oerlemans, J.: Global ice volume variations through the last glacial cycle simulated by a 3-D ice dynamical model, Quater. Int., 95-96, 11-23, 2002.

Bond, G., Broecker, W., Johnsen, S., McManus, J., Labeyrie, L., Jouzel, J., and Bonani, G.: Correlations between climate records from North Atlantic sediments and Greenland ice, Nature, 365, 143-147, 1993.

Brigham-Grette, J.: New perspectives on Berigian Quaternary paleogeography, stratigraphy and glacial history, Quater. Sci. Rev., 20, 15-24, 2001.

Charbit, S., Ritz, C., and Ramstein, G.: Simulations of Northern Hemisphere ice-sheet retreat: sensitivity to physical mechanisms involved during the Last Deglaciation, Quater. Sci. Rev., 21, 243-265, 2002.

Clague, J. J. and James, T. S.: History and isostatic effects of the last ice sheet in southern Bristish Columbia, Quater. Sci. Rev., 21, 71-87, 2002.

Clark, P. U. and Bartlein, P. J.: Correlation of Late Pleistocene glaciation in the western United States with North Atlantic Heinrich events, Geology, 23(6), 483-486, 1995.

Clark, P. U., Clague, J. J., Curry, B. B., Dreimanis, A., Hicock, S. R., Miller, G. H., Berger, G. W., Eyles, N., Lamothe, M., Miller, B. B., Mott, R. J., Oldale, R. N., Stea, R. R., Szabo, J. P., Thorleifson, L. H., and Vincent, J.-S.: Initiation and developement of the Laurentide and Cordilleran ice sheets following the last interglaciation, Quater. Sci. Rev., 12, 79-114, 1993.

CLIMAP: Seasonal reconstruction of the Earth surface at the Last Glacial Maximum. Geological Society of America, Boulder, Colorado, 1981.

Dansgaard, W., Johnsen, S. J., Clausen, H. B., Dahl-Jensen, D., Gundestrup, N. S., Hammer, C. U., Hvidberg, C. S., Steffensen, J. P., Sveinbjörnsdottir, A. E., Jouzel, J., and Bond, G.: Evidence for general instability of past climate from a 250-kyr ice-core record, Nature, 364, 218-220, 1993.

Deblonde, G. and Peltier, W. R.: Simulations of continental ice sheet growth over the last glacial-interglacial cycle: experiments with a one-level seasonal energy balance model including realistic geography, J. Geophys. Res., 96(D5), 9189-9215, 1991.

Deblonde, G., Peltier, W. R., and Hyde, W. T.: Simulations of continental ice sheet growth over the last glacial-interglacial cycle: 
experiments with a one-level seasonal energy balance model including seasonal ice albedo feedback, Palaeogeography, Palaeoclimatology, Palaeoecology (Global and Planeatry Change Section), 98, 37-55, 1992.

Dowdeswell, J. A.: The Greenland ice sheet and global sea-level rise, Science, 311, 963-964, 2006.

Dyke, A. S., Andrews, J. T., Clark, P. U., England, J. H., Miller, G. H., Shaw, J., and Veillette, J. J.: The Laurentide and Innuitian ice sheets during the Last Glacial Maximum, Quater. Sci. Rev., 21, 9-31, 2002.

Dyke, A. S. and Prest, V. K.: Late Wisconsinian and Holocene retreat of the Laurentide ice sheet, In: Geological Survey of Canada, Ottawa, Ontario, Map 1702A, scale: 1:500000, 1987.

Edwards, M. O.: Global gridded elevation and bathymetry (ETOPO5) digital raster data on a 5-minute geographic (lat $\times$ lon) $2160 \times 4320$ (centroid-registered) grid, National Oceanic and Atmospheric Administration, Boulder, Colorado, 1989.

Fairbanks, R. G.: A glacio-eustatic sea-level record: influence of glacial melting rates on the Younger Dryas event and deep ocean circulation, Nature, 342, 637-641, 1989.

Fleming, K., Johnston, P., Zwartz, D., Yokoyama, Y., Lambeck, K., and Chapell, J.: Refining the eustatic sea-level curve since the Last Glacial Maximum using far- and intermediate filed sites, Earth Planet. Sci. Lett., 163, 327-342, 1998.

Gallée, H., van Ypersele, J. P., Fichefet, T., Tricot, C., and Berger, A.: Simulation of the last glacial cycle by a coupled, sectorially averaged climate-ice-sheet model 2 . Response to insolation and $\mathrm{CO}_{2}$ variations, J. Geophys. Res., 97(D14), 15 713-15 740, 1992.

Greve, R., Weis, M., and Hutter, K.: Palaeoclimatic evolution and present conditions of the Greenland ice sheet in the vicinity of summit: an approach by large-scale modelling, Paleoclimates, 2(2-3), 133-161, 1998.

Huybrechts, P.: Sea-level changes at the LGM from ice-dynamic reconstructions of the Greenland and Antarctic ice sheets during the glacial cycles, Quater. Sci. Rev., 21, 203-231, 2002.

Johnsen, S. J., Dahl-Jensen, D., Dansgaard, D.. and Gundestrup, N.: Greenland paleotemperatures derived from GRIP bore hole temperature and ice core isotope profiles, Tellus, 47(B), 624$269,1995$.

Joseph, D.: Navy 10' global elevation values, National Center for Atmospheric Research, Boulder, Colorado, 3 pp., 1980.

Joussaume, S. and Taylor, K.: Status of the Paleoclimate Modelling Intercomparison Project (PMIP), in: First International AMIP Conference, Proceedings of the first international AMIP Conference, edited by: Gates, W. L., World. Meteorol. Organ., Geneva, pp. 425-430, 1995.

Kageyama, M., Charbit, S., Ritz, C., Khodri, M., and Ramstein, G.: Quantifying ice-sheet feedbacks during the last glacial inception, Geophys. Res. Lett., 31, L24203, doi:10.1029/2004GLO21339; 2004.

Kageyama, M., Laîné, A., Abe-Ouchi, A., Braconnot, P., Cortijo, E., Crucifix, M., de Vernal, A., Guiot, J., Hewitt, C. D., Kitoh, A., et al.: Last Glacial Maximum temperatures over the North Atlantic, Europe and Western Siberia: a comparison between PMIP models, MARGO sea-surface temperatures and pollen-based reconstructions, Quater. Sci. Rev., 25(17-18), 2082-2102, 2006.

Kineman, J.: FNOC/NCAR Global elevation, Terrain, and Surface Characteristics, Digital Dataset, 28MB; 1985.
Kleman, J., Fastook, J., and Stroeven, A. P.: Geologically and geomorphologically constrained numerical model of Laurentide ice sheet inception and build-up, Quater. Int., 95-96, 87-98, 2002.

Krinner, G., Boucher, O., and Balkanski, Y.: Ice-free northern Asia due to dust deposition on snow, Clim. Dyn., 27, 613-625, doi:10.1007/s00383-006-0159-z, 2006.

Lambeck, K.: Constraints on the Late Weichselian ice sheet over the Barents Sea from observations of raised shorelines, Quater. Sci. Rev., 14, 1-16, 1995.

Lambeck, K. and Chappell, J.: Sea level change through the last glacial cycle, Science, 292, 679-686, 2001.

Lambeck, K., Yokoyama, Y., Johnston, P., and Purcell, A.: Global ice volumes at the Last Glacial Maximum and early Lateglacial, Earth Planet. Sci. Lett., 181, 513-527, 2000.

Lambeck, K., Yokoyama, Y., and Purcell, T.: Into and out of the last glacial maximum: sea-level change during oxygen isotopes stages 3 and 2, Quater. Sci. Rev., 21, 343-360, 2002.

Lambeck, K., Purcell ,A., Funder, S., Kjaer, K. H., Larsen, E., and Moller, P.: Constraints on the Late Saalian to early Middle Weichselian ice sheet of Eurasia from field data and rebound modelling, Boreas, 35, 539-575, 2006.

Mann, D. H. and Hamilton, T. H.: Late Pleistocene and Holocene paleoenvironments of the North Pacific Coast, Quater. Sci. Rev., 14, 449-471, 1995.

Marshall, S. J., James, T. S., and Clarke, G. K. C.: North American ice sheet reconstructions at the Last Glacial Maximum, Quater. Sci. Rev., 21, 175-192, 2002.

Marshall, S. J., Sharp, M. J., Burgess, D. O., and Anslow, F. S.: Near-surface temperature lapse rates on the Prince of Wales icefield, Ellesmere Island, Canada: implications for regional downscaling of temperature, Int. J. Climatol., doi:10.1002/joc.1396, 2006.

Marshall, S. J., Tarasov, L., Clarke, G. K. C., and Peltier, W. R.: Glaciological reconstruction of the Laurentide Ice Sheet: physical processes and modelling challenges, Can. J. Earth Sci., 37, 769-793, 2000.

Marsiat, I.: Simulation of the Northern Hemisphere continental ice sheets over the last glacial interglacial cycle: experiments with a latitude-longitude vertically integrated ice sheet model coupled to a zonally averaged climate model, Paleoclimates, 1(1), 59-98, 1994.

Milne, G. A., Mitrovica, J. X., and Schrag, D. P.: Estimating past continental ice volume from sea-level data, Quater. Sci. Rev., 21, 361-376, 2002.

New, M., Hulme, M., and Jones, P.: Representing twentieth-century space-time climate variability. Part 1: Development of a 196190 mean monthly terrestrial climatology, J. Clim., 12, 829-856, 1999.

Ohmura, A. and Reeh, N.: New precipitation and accumulation maps for Greenland, J. Glaciol., 37, 140-148, 1991.

Peltier, W. R.: Ice age paleotopography, Science, 265, 195-201, 1994.

Peltier, W. R.: Global glacial isostasy and the surface of the ice-age Earth: the ICE-5G (VM2) model and GRACE, Ann. Rev. Earth Planet. Sci., 32, 111-149, 2004.

Peltier, W. R. and Marshall, S.: Coupled energy-balance/ice-sheet model simulations of the glacial cycle: A possible connection between terminations and terrigeneous dust, J. Geophys. Res. Lett., 100(D7), 14 269-14 289, 1995. 
Peyaud, V., Rôle de la dynamique des calottes glaciaires dans les grands changements climatiques des périodes glaciairesinterglaciaires, $\mathrm{PhD}$ thesis, Joseph-Fourier University, Grenoble, France, 2006.

Pollard, D. and Groups, P. P.: Comparisons of ice-sheet surface mass budgets from Paleoclimate Modeling Intercomparison Project (PMIP) simulations, Global Planet. Change, 24, 79-106, 2000.

Raynaud, D., Jouzel, J., Barnola, J.-M., Chappelaz, J., Delmas, R. J., and Lorius, C.: The ice record of greenhouse gases, Science, 259, 926-934, 1993.

Reeh, N.: Parameterization of melt rate and surface temperature on the Greenland ice sheet, Polarforschung, 59, 113-128, 1991.

Reimer, P. J., Baillie, M. G. L., Bard, E., Bayliss, A., Warren Beck, J., Bertrand, C. J. H., Blackwell, P. G., Buck, C. E., Burr, G. S., Cutler, K. B., et al.: IntCal04 Terrestrial radiocarbon age calibration 0-26 kyr BP, Radiocarbon, 46(3), 1029-1058, 2004.

Reynolds, R. W.: A real-time global sea-surface temperature analysis, J. Clim., 1, 75-86, 1988.

Rignot, E. and Kanagaratnam, P.: Changes in the velocity structure of the Greenland ice sheet, Science, 311, 986-990, 2006.

Ritz, C., Fabre, A., and Letréguilly, A.: Sensitivity of a Greenland ice sheet model to ice flow and ablation parameters: consequences for the evolution through the last climatic cycle, Clim. Dyn., 13, 11-24, 1997.

Ritz, C., Rommelaere, V., and Dumas, C.: Modeling the Antarctic ice sheet evolution of the last 420000 years: implication for altitude changes in the Vostok region, J. Geophys. Res., 106(D23), 31 943-31 964, 2001.

Roe, G. H. and Lindzen, R. S.: The mutual-interaction between continental-scale ice-sheets and atmospherice stationary waves, J. Clim., 14(7), 1450-1465, 2001.

Serreze, M. C. and Hurst, C. R.: Representation of mean Arctic precipitation from NCEP-NCAR and ERA reanalyses, J. Clim., 13, 182-201, 2001.

Shea, D. J., Trenberth, K. E., and Reynolds, R. W.: A global monthly sea-surface temperature climatology, NCAR technical note, NCAR/TN-345, 167pp, 1990.
Siegert, M. J., Dowdeswell, J. A., Hald, M., and Svendsen, J. I.: Modelling the Eurasian ice sheet through a full (Weichselian) glacial cycle, Global Planet. Change, 31, 367-385, 2001.

Siegert, M. J., Dowdeswell, J. A., and Melles, M.: Late Weichselian Glaciation of the Russian high Arctic, Quater. Res., 52, 273-285, 1999.

Svendsen, J. I., Alexanderson, H., Astakhov, V. I., Demidov, I., Dowdeswell, J., Funder, S., Gataullin, V., Henriksen, M., Hjort, C., Houmark-Nielsen, M., et al.: Late Quaternary ice sheet history of Northern Eurasia, Quater. Sci. Rev., 23, 1229-1271, 2004.

Tarasov, L. and Peltier, W. R.: Terminating the $100 \mathrm{kyr}$ ice age cycle, J. Geophys. Res., 102(D18), 21 665-21 693, 1997.

Tarasov, L. and Peltier, W. R.: Impact of thermomechanical ice sheet coupling of the $100 \mathrm{kyr}$ ice age cycle, J. Geophys. Res., 104(D8), 9517-9545, 1999.

Tarasov, L. and Peltier, W. R.: A geophysically constrained large ensemble analysis of the deglacial history of the North American ice sheet complex, Quater. Sci. Rev., 23, 359-388, 2004.

Vartanyan, S. L., Arskhanov, Kh. A., Tertychnaya, T. V., and Chernov, S. B.: Radiocarbon dating evidence for mammoths on Wrangel Island, Artic Ocean, until 2000 BC, Radiocarbon, 37(1), $1-6,1995$.

Waelbroeck, C., Labeyrie, L., Michel, E., Duplessy, J. C., McManus, J. F., Lambeck, K., Balbon, E., and Labracherie, M. Sea-level and deep water temperature changes derived from benthic foraminifera isotopic records, Quater. Sci. Rev., 21, 295305, 2002.

Yokoyama, Y., Lambeck, K., De Dekker, P., Johnston, P., and Fifield, L. K.: Timing of the Last Glacial Maximum from observed sea-level minima, Nature, 406, 713-716, 2000.

Zweck, C. and Huybrechts, P.: Modeling of the northern hemisphere ice sheets during the last glacial cycle and glaciological sensitivity, J. Geophys. Res., 110, D07103, doi:10.1029/2004JD005489, 2005. 